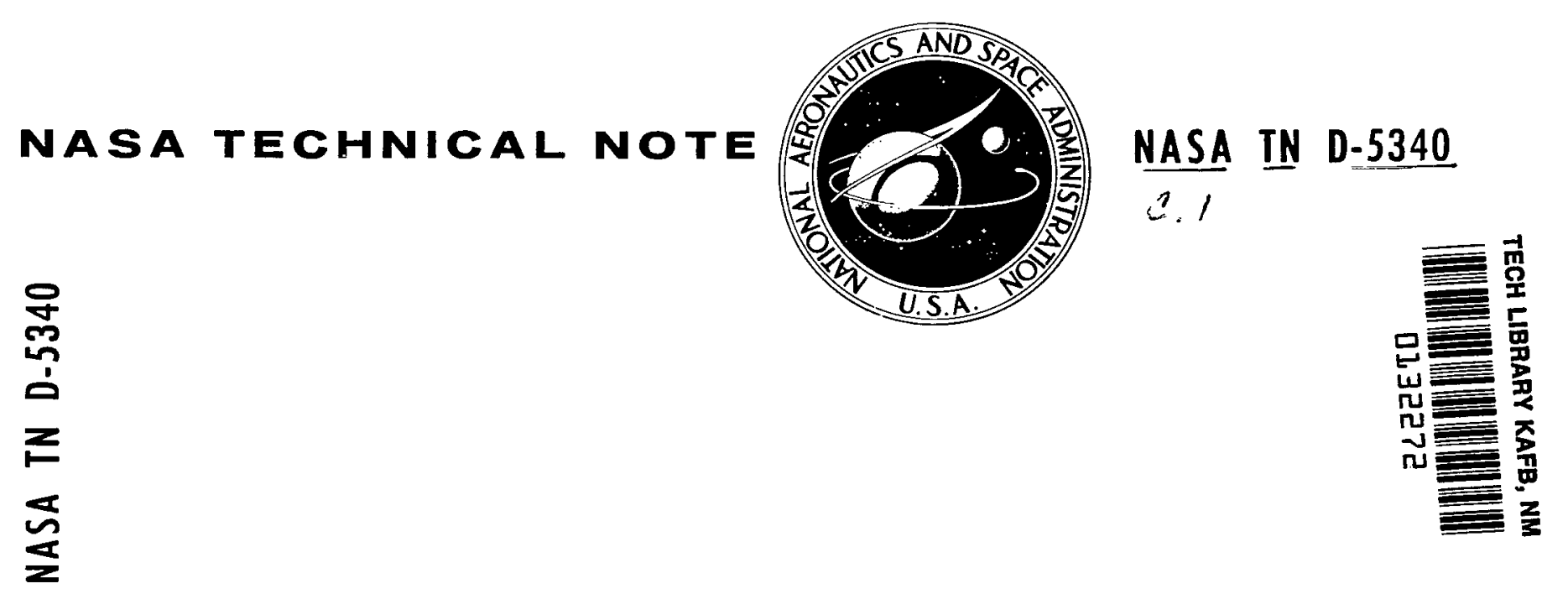

\title{
A SEMIEMPIRICAL FRACTURE ANALYSIS FOR SMALL SURFACE CRACKS
}

by Thomas W. Orange

Lewis Research Center Cleveland, Obio 


\section{A SEMIEMPIRICAL FRACTURE ANALYSIS}

FOR SMALL SURFACE CRACKS

By Thomas W. Orange

Lewis Research Center

Cleveland, Ohio

\section{NATIONAL AERONAUTICS AND SPACE ADMINISTRATION}

For sale by the Clearinghouse for Federal Scientific and Technical Informotion Springfield, Virginia 22151 - CFSTI price $\$ 3.00$ 


\section{ABSTRACT}

A semiempirical modification of Irwin's fracture analysis for a semielliptical surface crack in a plate is proposed. When it is applied to surface crack test data from the literature, a single toughness parameter is obtained which relates fracture stress to crack size with reasonable accuracy. The method appears usable when crack size and material thickness are too small to allow a valid analysis using conventional fracture mechanics principles. It is even effective when fracture stresses are above yield. A similiar analysis for through-the-thickness cracks is discussed but not evaluated. Application to low-cycle fatigue crack propagation studies is proposed. 


\section{A SEMIEMPIRICAL FRACTURE ANALYSIS FOR SMALL SURFACE CRACKS \\ by Thomas W. Orange \\ Lewis Research Center}

\section{SUMMARY}

This report presents a semiempirical modification of Irwin's fracture analysis for a semielliptical surface crack in a plate. The plastic zone correction factor is replaced by a term chosen so that the modified Irwin equation predicts fracture at ultimate tensile strength for zero crack depth. The effects of normal experimental error and material property variations are considered, and a statistical procedure for averaging the results of a series of tests is presented. A similar analysis for through-thethickness cracks is discussed but not evaluated.

Surface-crack test data from the literature (for aluminum, magnesium, titanium, and steel alloys and aluminum weldments) are analyzed. The method yields a toughness parameter for each material which relates fracture stress to crack size, generally within about \pm 5 percent. The method appears to be usable when crack size and material thickness are too small to allow a valid fracture mechanics analysis. It is even effective when fracture stresses are above yield.

At present the analysis is limited to crack depths less than about half the material thickness. The available data are not sufficient to determine whether the modified toughness parameter is independent of material thickness.

\section{INTRODUCTION}

The most well known fracture analysis for surface cracks is that of Irwin (ref. 1). This analysis relates the fracture stress for a specimen or structure containing a semielliptical surface crack to the crack dimensions, the material's yield strength, and a material constant called the plane strain fracture toughness and designated $\mathrm{K}_{\mathrm{IC}}$.

The application of this analysis to practical problems is not always straightforward. As explained in reference 1 , the analysis is considered valid only when the crack depth is less than half the material thickness and when the gross stress at fracture is less than 
the material's yield strength. The specimen necessary to determine $\mathrm{K}_{\mathrm{IC}}$ (ref. 2) may be many times thicker than in the intended application, and the applicability of thicksection laboratory data to thin-section hardware is questionable.

When the Irwin analysis is used to predict fracture stress and the crack depth approaches zero, the predicted fracture stress is more than twice the material's yield strength. It may be meaningless to speak of zero crack depth in relation to engineering materials that contain microscopic defects and inhomogeneities. But for engineering use, the fracture stress for a vanishingly small crack should be the material's ultimate tensile strength.

In the present report, Irwin's plastic zone correction factor is replaced by a term chosen so that the modified equation predicts fracture at ultimate tensile strength when the crack depth is reduced to zero. McClintock and Irwin (ref. 3) state that until suitable elastic-plastic analyses are available, empirical adjustments of the plastic zone correction factor can be justified. Application of the same principle to Irwin's fracture equation for through-the-thickness cracks is discussed, but the available data are either unsuitable or insufficient for a critical evaluation.

\title{
SYMBOLS
}

\author{
a crack depth \\ c one-half crack length \\ i index in summation \\ $\mathrm{K}_{\mathrm{IC}} \quad$ opening-mode (plane strain) fracture toughness \\ $\mathrm{K}_{\mathrm{IU}} \quad$ modified $\mathrm{K}_{\mathrm{IC}}$ \\ $\mathrm{K}_{\mathrm{c}} \quad$ mixed-mode (plane stress) fracture toughness \\ $\mathrm{K}_{\mathrm{u}} \quad$ modified $\mathrm{K}_{\mathrm{c}}$ \\ t specimen thickness \\ W specimen width \\ $\Delta \quad$ expected error; read, "expected error in . . ." \\ $\sigma \quad$ gross stress at fracture \\ $\sigma_{\mathbf{u}} \quad$ material ultimate strength \\ $\sigma_{\text {ys }} \quad$ material tensile yield strength ( 0.2 percent offset) \\ $\theta \quad$ variable of integration \\ $\Phi \quad$ complete elliptic integral of the second kind
}




\section{ANALYSIS FOR SURFACE CRACKS}

\section{Irwin Analysis}

In its fundamental form, Irwin's fracture equation for a semielliptical surface crack is (from ref. 1)

$$
\mathrm{K}_{\mathrm{IC}}^{2}=\frac{1.2 \pi \sigma^{2}}{\Phi^{2}}\left[\mathrm{a}+\frac{1}{4 \sqrt{2} \pi}\left(\frac{\mathrm{K}_{\mathrm{IC}}}{\sigma_{\mathrm{ys}}}\right)^{2}\right]
$$

where

$$
\Phi=\int_{0}^{\pi / 2} \sqrt{1-\left(1-\frac{a^{2}}{c^{2}}\right) \sin ^{2} \theta} d \theta
$$

Here, the second term in the brackets represents the plastic zone correction term. It was assumed by Irwin that the effects of localized yielding at the crack tip may be accounted for by adding a portion of the plastic zone to the actual crack depth. For convenience, equation (1a) is usually written as

$$
\mathrm{K}_{\mathrm{IC}}^{2}=\frac{1.2 \pi \mathrm{a} \sigma^{2}}{\Phi^{2}-0.212\left(\frac{\sigma}{\sigma_{\mathrm{ys}}}\right)^{2}}
$$

or in terms of fracture stress as

$$
\sigma=\mathrm{K}_{\mathrm{IC}} \div \sqrt{\frac{1.2 \pi \mathrm{a}}{\Phi^{2}}+\frac{0.212}{\Phi^{2}}\left(\frac{\mathrm{K}_{\mathrm{IC}}}{\sigma_{\mathrm{ys}}}\right)^{2}}
$$

The preceeding equation may be written in terms of the normalized crack depth a/ $\Phi^{2}$ by assuming that $\Phi^{2}=\sqrt{2}$ in the second term under the radical, giving

$$
\sigma \approx \mathrm{K}_{\mathrm{IC}} \div \sqrt{1.2 \pi \frac{\mathrm{a}}{\Phi^{2}}+0.15\left(\frac{\mathrm{K}_{\mathrm{IC}}}{\sigma_{\mathrm{ys}}}\right)^{2}}
$$


This assumption is equivalent to assuming that $a / 2 c \approx 0.23$. Since only the plastic zone correction is affected, any error in $\sigma$ should be small.

Because it is based on linear elastic theory, the analysis is not valid if the fracture stress is greater than yield. Brown and Srawley (ref. 2) indicate that it is valid (i.e., measured $\mathrm{K}_{\mathrm{IC}}$ is constant) only when the crack depth is greater than about $2 \frac{1}{2}$ times the square of the ratio of $\mathrm{K}_{\mathrm{IC}}$ to yield strength. Because of geometrical considerations, it is restricted to crack depths less than half the material thickness. Thus application of Irwin's analysis to material thicknesses less than about $5\left(\mathrm{~K}_{\mathrm{IC}} / \sigma_{\mathrm{ys}}\right)^{2}$ is uncertain.

\section{Modified Irwin Analysis}

By altering only the plastic zone correction term, Irwin's equation can be made to predict fracture at ultimate strength for zero crack depth. This is done by replacing fracture stress with ultimate strength and crack depth with zero in equation (1a), then solving for the new "plastic zone correction factor." The equation then becomes

$$
\mathrm{K}_{\mathrm{IU}}^{2}=\frac{1.2 \pi \sigma^{2}}{\Phi^{2}}\left[\mathrm{a}+\frac{\Phi^{2}}{1.2 \pi}\left(\frac{\mathrm{K}_{\mathrm{IU}}}{\sigma_{\mathrm{u}}}\right)^{2}\right]
$$

which can be written as

$$
\mathrm{K}_{\mathrm{IU}}^{2}=\frac{1.2 \pi \mathrm{a} \sigma^{2}}{\left.\Phi^{2}\left[1-\left(\frac{\sigma}{\sigma}\right)^{2}\right)^{2}\right]}
$$

or

$$
\sigma=\mathrm{K}_{\mathrm{IU}} \div \sqrt{1.2 \pi \frac{\mathrm{a}}{\Phi^{2}}+\left(\frac{\mathrm{K}_{\mathrm{IU}}}{\sigma_{\mathrm{u}}}\right)^{2}}
$$

The modified fracture toughness parameter is designated $\mathrm{K}_{\mathrm{IU}}$ to distinguish it from the Irwin parameter $\mathrm{K}_{\mathrm{IC}}$. For a given crack size and fracture stress, $\mathrm{K}_{\mathrm{IU}}$ is almost always greater than $\mathrm{K}_{\mathrm{IC}}$. However, when fracture stress is very much less than yield or ultimate (as for a large crack in a brittle material), 


$$
\mathrm{K}_{\mathrm{IU}}=\mathrm{K}_{\mathrm{IC}} \approx \sigma \sqrt{1.2 \pi \frac{\mathrm{a}}{\Phi^{2}}}
$$

Since only the plastic zone corrections differ, this analysis and Irwin's must be subject to the same geometrical restrictions. Irwin estimated that his analysis will be reasonably accurate as long as the crack depth is less than half the material thickness. If the crack depth is large with respect to the thickness, the effect of the free back surface is to increase the actual stress intensity at the crack tip. Equation (1a) then underestimates the actual stress intensity, and the apparent stress intensity decreases with increasing $a / t$. Thus, unless there is firm evidence to the contrary, the modified Irwin analysis should also be restricted to cases where the crack depth is less than half the material thickness.

Other researchers, notably Kobayashi (ref. 4) and Smith (ref. 5), have developed correction factors for deep flaws. It should be possible to combine the elastic portion of such a deep-flaw analysis with the plastic zone correction of the present analysis. However, this was not attempted here.

Equation (2b) breaks down if the fracture stress is not less than the tensile ultimate strength. This phenomenon sometimes occurs and is usually called "notch strengthening." In such a case, a correlation based on an artificially elevated ultimate strength value might be possible but is beyond the scope of this report.

\section{Expected Error}

In an experimental determination of $\mathrm{K}_{\mathrm{IU}}$, the error $\Delta \mathrm{K}_{\mathrm{IU}}$ to be expected due to the normal variation of material properties and due to imprecision of physical measurements is

$$
\Delta \mathrm{K}_{\mathrm{IU}}=\left|\frac{\partial \mathrm{K}_{\mathrm{IU}}}{\partial \frac{\mathrm{a}}{\Phi^{2}}}\right| \Delta \frac{\mathrm{a}}{\Phi^{2}}+\left|\frac{\partial \mathrm{K}_{\mathrm{IU}}}{\partial \sigma}\right| \Delta \sigma+\left|\frac{\partial \mathrm{K}_{\mathrm{IU}}}{\partial \sigma_{\mathrm{u}}}\right| \Delta \sigma_{\mathrm{u}}
$$

Differentiating equation (2b) yields

$$
\Delta \mathrm{K}_{\mathrm{IU}}=\mathrm{K}_{\mathrm{IU}}\left[\frac{\Phi^{2}}{2 \mathrm{a}} \Delta \frac{\mathrm{a}}{\Phi^{2}}+\frac{1}{1-\left(\frac{\sigma}{\sigma_{\mathrm{u}}}\right)^{2}} \frac{\Delta \sigma}{\sigma}+\frac{\left(\frac{\sigma}{\sigma_{\mathrm{u}}}\right)^{2}}{1-\left(\frac{\sigma}{\sigma_{\mathrm{u}}}\right)^{2}} \frac{\Delta \sigma_{\mathrm{u}}}{\sigma_{\mathrm{u}}}\right]
$$


In this report it is assumed that $\Delta\left(\mathrm{a} / \Phi^{2}\right)=0.0006 \mathrm{inch}(0.015 \mathrm{~mm}), \Delta \sigma / \sigma=0.03$, and $\Delta \sigma_{\mathrm{u}} / \sigma_{\mathrm{u}}=0.03$. The expected error in a $/ \Phi^{2}$ corresponds to a 0.001 inch $(0.025 \mathrm{~mm})$ error in crack depth measurement for a crack with a shape factor $a / 2 c \approx 0.31$. The expected errors in fracture stress and ultimate strength are considered to be normal, representative precision levels for careful tests involving parent metal (for weldment tests, however, somewhat larger values might be more appropriate). Using these values, the previous equation then becomes

$$
\Delta \mathrm{K}_{\mathrm{IU}}=\overline{\mathrm{K}_{\mathrm{IU}}}\left[\frac{1+\left(\frac{\sigma}{\sigma_{\mathrm{u}}}\right)^{2}}{\frac{0.0003}{\Phi^{2}}+0.03 \frac{\mathrm{a}}{\left(\frac{\sigma}{\sigma_{\mathrm{u}}}\right)^{2}}}\right]
$$

or, when written in terms of $\mathrm{a} / \Phi^{2}$ or $\sigma / \sigma_{\mathrm{u}}$ only

$$
\begin{aligned}
& \Delta \mathrm{K}_{\mathrm{IU}}=\overline{\mathrm{K}}_{\mathrm{IU}}\left\{0.03+\frac{1}{\frac{\mathrm{a}}{\Phi^{2}}}\left[0.0003+\frac{0.05}{\pi}\left(\overline{\frac{\mathrm{K}_{\mathrm{IU}}}{\sigma_{\mathrm{u}}}}\right)^{2}\right]\right\} \\
& \Delta \mathrm{K}_{\mathrm{IU}}=\overline{\mathrm{K}_{\mathrm{IU}}}\left\{0.03+\frac{\left(\frac{\sigma}{\sigma_{\mathrm{u}}}\right)^{2}}{1-\left(\frac{\sigma}{\sigma_{\mathrm{u}}}\right)^{2}}\left[\frac{0.00036 \pi}{\left(\frac{\mathrm{K}_{\mathrm{IU}}}{\sigma_{\mathrm{u}}}\right)^{2}}+0.06\right]\right\}
\end{aligned}
$$

where $\overline{\mathrm{K}_{\mathrm{IU}}}$ is the "true" value (or the weighted average value; see next section).

From equation (4b) the maximum stress ratio $\sigma / \sigma_{\mathrm{u}}$ for a given allowable error $\Delta \mathrm{K}_{\mathrm{IU}} / \overline{\mathrm{K}_{\mathrm{IU}}}$ can be determined. This is shown for range of $\overline{\mathrm{K}_{\mathrm{IU}}} / \sigma_{\mathrm{u}}$ observed for the data examined in this report as follows:

\begin{tabular}{|l|l|l|l|l|l|l|l|l|l|}
\hline & \multicolumn{8}{|c}{$\Delta \mathrm{K}_{\mathrm{IU}} \overline{\mathrm{K}_{\mathrm{IU}}}$} \\
\cline { 2 - 5 } & \multicolumn{2}{|c|}{0.20} & \multicolumn{2}{|c|}{0.10} & 0.05 \\
\hline$\overline{\mathrm{K}_{\mathrm{IU}}} / \sigma_{\mathrm{u}}$ & 0.2 & 0.5 & 1.0 & 0.2 & 0.5 & 1.0 & 0.2 & 0.5 & 1.0 \\
$\left(\sigma / \sigma_{\mathrm{u}}\right)_{\max }$ & .81 & .85 & .86 & .67 & .72 & .73 & .43 & .49 & .50
\end{tabular}


The $\left(\sigma / \sigma_{\mathrm{u}}\right)_{\max }$ values are valid only for $\Delta\left(\mathrm{a} / \Phi^{2}\right)=0.006 \mathrm{inch}, \Delta \sigma / \sigma=0.03$, and $\Delta \sigma_{u} / \sigma_{u}=0.03$.

In the same manner as for equation (3), the expected error in $\mathrm{K}_{\mathrm{IC}}$ can be determined as

$$
\Delta \mathrm{K}_{\mathrm{IC}} \approx \overline{\mathrm{K}}_{\mathrm{IC}}\left(\frac{0.0003}{\frac{\mathrm{a}}{\Phi^{2}}}+0.05 \frac{\Phi^{2}}{\mathrm{Q}}-0.02\right)
$$

where $\mathrm{Q}=\left[\Phi^{2}-0.212\left(\sigma / \sigma_{\mathrm{ys}}\right)^{2}\right]$ and $\Delta \sigma_{\mathrm{ys}} / \sigma_{\mathrm{ys}}$ is assumed to be 0.02 . As before, this error is considered to be representative of a careful test.

\section{Weighted Average}

As flaw size decreases, the expected error in $\mathrm{K}_{\mathrm{IU}}$ (eq. (3)) increases. But as flaw size decreases, fracture stress tends to increase, and the error in $\mathrm{K}_{\mathrm{IU}}$ is compounded. Thus for small flaws, $\mathrm{K}_{\mathrm{IU}}$ measurements are very sensitive to small experimental errors and material property variations. It is desirable, then, to average the results of as many tests as possible.

If the tests cover a range of flaw size and/or fracture stress, they will not all have the same precision. According to Wilson (ref. 6) the observations should be weighted inversely proportional to the square of their expected error. The weighted average value of $\mathrm{K}_{\mathrm{IU}}$ is then

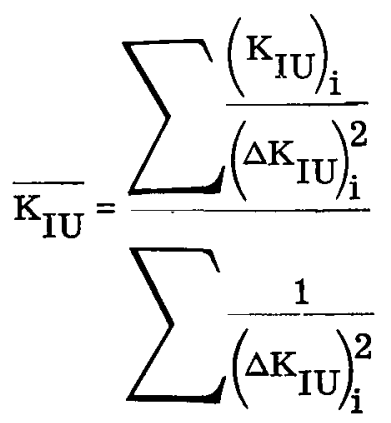

where $\Delta \mathrm{K}_{\mathrm{IU}}$ is given by equation (3).

The inverse-square weighting procedure and the nature of the error function combine to weight the large-flaw, low-stress tests very heavily. For example, if $\overline{\mathrm{K}_{\mathrm{IU}}} / \sigma_{\mathrm{u}}=0.5$, a test at $\sigma=0.5 \sigma_{\mathrm{u}}$ is weighted 35 times as much as a test where $\sigma=0.9 \sigma_{u}$. It is desirable to place more weight on the test expected to be the most precise, but the weighting function given by equation (6) and (3) appears to be unusually 
severe. Perhaps, it would suffice to weight inversely proportional to the expected error rather than to its square. However, the use of the second power is customary statistical procedure. Also, as will be shown later, the use of equation (6) results in a fairly accurate correlation of fracture stress with crack size for several materials.

It should be noted that this weighted averaging procedure is not the same as a conventional curve fit. There, one might mathematically determine the value of $\mathrm{K}_{\mathrm{IU}}$ which minimizes the sum of the squares of the fracture stress deviations (differences between stress observed and stress predicted by eq. (2c)). The weighted average, however, is based on a prior assumption of the magnitudes of the errors that might be expected and on the knowledge of the effect such errors will have on the calculated value of $\mathrm{K}_{\mathrm{IU}}$.

It is difficult to determine whether the variations in apparent $K_{I U}$ for some sets of data represent a real trend or merely confirm the error expectation. Error analysis cannot prove that $\mathrm{K}_{\mathrm{IU}}$ is a material constant. It can only show that, if $\mathrm{K}_{\mathrm{IU}}$ is a constant, the variations are within the bounds of expected error. However, it will be assumed in this report that $\mathrm{K}_{\mathrm{IU}}$ is a constant and that the weighted average (eq. (6)) is a suitable operating definition.

A similar weighted averaging procedure should be used for a set of $\mathrm{K}_{\mathrm{IC}}$ values, but only for the domain where $\mathrm{K}_{\mathrm{IC}}$ is reasonably constant. The rationale of linear elastic fracture mechanics does not allow the consideration of apparent $\mathrm{K}_{\mathrm{IC}}$ values obtained outside that domain.

\section{ANALYSIS FOR THROUGH CRACKS}

The conventional fracture equation for a centrally cracked sheet is (from ref. 7)

$$
\mathrm{K}_{\mathrm{c}}^{2}=\sigma^{2} \mathrm{~W} \tan \left[\frac{\pi \mathrm{c}}{\mathrm{W}}+\frac{1}{2 \mathrm{~W}}\left(\frac{\mathrm{K}_{\mathrm{c}}}{\sigma_{\mathrm{ys}}}\right)^{2}\right]
$$

As was done for the surface crack, equation (7) may be modified to predict fracture at ultimate strength for zero crack length. The modified equation is

$$
\mathrm{K}_{\mathrm{u}}^{2}=\sigma^{2} \mathrm{~W} \tan \left[\frac{\pi \mathrm{c}}{\mathrm{W}}+\arctan \frac{1}{\mathrm{~W}}\left(\frac{\mathrm{K}_{\mathrm{u}}}{\sigma_{\mathrm{u}}}\right)^{2}\right]
$$

The modified fracture toughness parameter is called $K_{u}$ to distinguish it from the conventional parameter $K_{c}$. 
The lack of suitable data and the uncertainties associated with mixed-mode fracture testing do not allow a critical evaluation of equation (8). However, it is presented here for possible future evaluation.

\section{APPLICATION TO DATA FROM THE LITERATURE}

To test the present analysis, sets of surface-crack test data were selected from the literature. These data cannot be analyzed by conventional fracture mechanics procedures. The tests do not meet the criteria (discussed previously) for a valid test and, indeed, the apparent $\mathrm{K}_{\mathrm{IC}}$ values obtained were not constant. Published data that covered only a limited flaw size range or which exhibited unusually severe scatter were not considered.

These test data from the literature, along with the pertinent parameters (calculated at NASA Lewis), are tabulated in tables $I$ to $V$ at the end of this report. Where important material properties were not reported, they are estimated on the basis of the best available information.

\section{Battelle Memorial Institute Data for Titanium Alloy}

These data (from ref. 8) are examined first as they represent the largest sample size and show some interesting trends. The material is a titanium alloy (6Al-4V) solutiontreated and aged, and the specimens were $0.020,0.040$, and 0.060 inch $(0.5,1.0$, and $1.5 \mathrm{~mm}$ ) thick.

Figure 1(a) shows apparent $\mathrm{K}_{\mathrm{IC}}$ (eq. (1b)) to be a unique function of the normalized crack depth $\mathrm{a} / \Phi^{2}$ and independent of material thickness for these tests. The target flaw depths were 25, 50, and 75 percent of each thickness. About half the flaws were actually deeper than half thickness. As discussed earlier, apparent $\mathrm{K}_{\mathrm{IC}}$ values are usually depressed for crack depths greater than half the thickness. Thus, one would expect a lower $K_{I C}$ value for a very deep flaw in a thin specimen than for the same size flaw in much thicker material. However, no such deep-flaw effect can be seen here.

On first examination of figure $1(a)$, one might conclude that apparent $K_{I C}$ is reasonably constant for $a / \Phi^{2}>0.025$ inch $(0.63 \mathrm{~mm})$ and is about $50 \mathrm{ksi} \sqrt{\text { in. }}$ $\left(55 \mathrm{MNm}^{-3 / 2}\right)$. If so, the minimum crack depth for a valid test (ref. 2) would be $2 \frac{1}{2}\left(\mathrm{~K}_{\mathrm{IC}} / \sigma_{\mathrm{ys}}\right)^{2}=2 \frac{1}{2}(50 / 160)^{2}=0.24 \mathrm{inch}(6.2 \mathrm{~mm})$. This is about five tiries as large as the deepest crack actually tested. Therefore, the preliminary conclusion is unfounded, and the data should not be analyzed using conventional fracture mechanics procedures. 
For each specimen the modified fracture toughness parameter $\mathrm{K}_{\mathrm{IU}}$ was computed using equation (2b). The weighted average $\mathrm{K}_{\mathrm{IU}}$ (eq. (6)) was calculated and then used to determine the expected error (eqs. (4a) and (b)). The four specimens having $a / \Phi^{2} \sim$ 0.04 inch $(1 \mathrm{~mm})$ were excluded from the weighted average because, for them, the apparent absence of depth-to-thickness effect is unconfirmed; that is, there are no tests with the same flaw size in a thicker material (such that $a / t<\frac{1}{2}$ ) giving the same apparent $\mathrm{K}_{\mathrm{IC}}$ value. For the remaining specimens, however, the absence of depth-tothickness effect is evident. Thus, for these specimens only, the limitation recommended by $\operatorname{Irwin}\left(\mathrm{a} / \mathrm{t}<\frac{1}{2}\right)$ was ignored.

In figures $1(\mathrm{~b})$ and (c) the computed $\mathrm{K}_{\mathrm{IU}}$ values and expected error bands are plotted. The observed $\mathrm{K}_{\mathrm{IU}}$ values are, in general, evenly distributed within the bounds of expected error. These same figures also illustrate the large variation in $\mathrm{K}_{\mathrm{IU}}$ to be expected for tests with small cracks and resulting high fracture stresses.

In figure 1(d), fracture stress is predicted using equation (2c) and the weighted average $\mathrm{K}_{\mathrm{IU}}$. Note that the fracture stress for zero crack size is the material's ultimate strength. Except for the largest cracks, equation (2c) correctly predicts the shape of the fracture stress - flaw size curve and the data are within about \pm 5 percent of the predicted value. This degree of accuracy is probably sufficient for most engineering purposes.

Even though a good correlation was obtained, the problem of partial-thickness cracks in the thin sheet can still be subject to further scrutiny. For the data shown in figure 1 an equally good correlation can be made by treating the surface crack as a through-crack of the same length. Using equation (8), an average nominal value (based on original crack length) of $\mathrm{K}_{\mathrm{u}}$ was determined for the four largest cracks. This value was then used in equation (8) to predict fracture stress as a function of crack length only. As can be seen in figure 2, the data agree with predicted stresses within about \pm 6 percent.

For this material and thickness range, then, we can predict fracture based on either crack length or (normalized) crack depth. From an inspection standpoint, the correlation based on surface crack length would be preferred. But, if we wish to step outside the narrow boundaries of these tests, we must know which of these correlations might be accidental and which (if, indeed, either) is applicable to other cases. For the thicker materials to be examined later, correlations based on crack length are not adequate.

\section{Lockheed Missiles \& Space Co. Data for Magnesium Alloy}

Reference 9 presents surface-crack test data for the magnesium alloy HM21A-T8 in 0.143 -inch $(3.6-\mathrm{mm})$ thickness. For all these tests the fracture stresses were greater than the material's yield strength. These tests are clearly outside the domain of linear 
elastic fracture mechanics. As expected, the apparent $\mathrm{K}_{\mathrm{IC}}$ values (fig. 3(a)) are not constant. The calculated $\mathrm{K}_{\mathrm{IU}}$ values (figs. $3(\mathrm{~b})$ and (c)) are generally within the boundaries of expected error but appear to cluster along the upper bound. Whether this is due to a nonrandom error or to a systematic variable is not clear.

In analyzing these data the crack depth limitation suggested by Irwin $\left(a / t<\frac{1}{2}\right)$ was observed, there being no evidence to justify ignoring it. Specifically, specimens having cracks deeper than half the thickness were excluded from all further consideration. The computed fracture stress (fig. 3(d)) fits the data reasonably well. Again, it should be noted that an analysis of these data could not have been made at all using conventional elastic fracture mechanics.

Similar results for this same material in the transverse grain direction are shown in figure 4 . Since they differ only quantitatively from the longitudinal direction they will not be discussed further.

Note the four longitudinal specimens (fig. 3) and the five transverse specimens (fig. 4) having crack size factors greater than 0.06 inch $(1.5 \mathrm{~mm})$. Lower values of $\sigma$ and $\mathrm{K}_{\mathrm{IC}}$ were obtained from the narrower specimens, which suggests that they were not wide enough to simulate an infinite plate containing a flaw of this size. A discussion of finite-width effects in surface-cracked specimens is beyond the scope of this report. However, the point is called to the reader's attention.

\section{Douglas Aircraft Co. Data for Several Alloys and Weldments}

Reference 10 reports surface-crack test data for 3/8-inch (9.5-mm) thick 2014$\mathrm{T} 651$ aluminum alloy at $-423^{\circ} \mathrm{F}(20 \mathrm{~K})$. Figure 5 shows the variation of $\mathrm{K}_{\mathrm{IC}}$ and fracture stress with crack size. The predicted fracture stress (based on $\mathrm{K}_{\mathrm{IU}}$ ) fits the data very well.

Additional tests reported in reference 10 for 4340 alloy steel $1 / 4$ inch $(6.3 \mathrm{~mm})$ thick are shown in figure 6 . Good agreement between calculated and observed fracture stress is obtained here also.

Reference 11 contains surface crack data for 0.10 - and 0.25 -inch (2.5- and 6.3-mm) thick 2014-T6 aluminum alloy tested at room temperature and $-423^{\circ} \mathrm{F}(20 \mathrm{~K})$. The variations of $K_{\mathrm{IC}}$ and fracture stress with crack size are shown in figures 7 and 8. The fracture stress prediction is good at room temperature and very good at $-423^{\circ} \mathrm{F}$ $(20 \mathrm{~K})$. The room-temperature ultimate strength values represent but a single test for each thickness and must be judged accordingly. If they were but 5 percent higher (which would not be atypical) the correlations would be even better. Note also that most fracture stresses are above yield. 
Reference 12 presents some interesting and very informative data on the behavior of surface cracks in 2014-T6 aluminum alloy parent metal and weldments 0.25 inch $(6.3 \mathrm{~mm})$ thick at room temperature and $-423^{\circ} \mathrm{F}(20 \mathrm{~K})$. The problem of surface cracks in welds is especially important to the design of spacecraft propellant tanks, as welds are often the most likely places for cracks to form and propagate. But because the yield strength is low, the minimum specimen needed for a valid $\mathrm{K}_{\mathrm{IC}}$ test is often unrealistically large. Figures 9 to 11 show the variation of $\mathrm{K}_{\mathrm{IC}}$ and fracture stress with crack size for parent metal, welds with 4043 filler wire, and welds with 716 filler wire, respectively. Correlation for all three cases is very good, especially since scatter for weldment tests is often severe.

\section{Effect of Material Thickness}

Figures 5 and 7 to 9 illustrate the range of $\overline{\mathrm{K}_{\mathrm{IU}}}$ values observed for what is nominally a single material, 2014-T6 aluminum alloy. Unfortunately, there are too many extraneous variables (composition, temperature, grain direction, and strength level). A series of tests where thickness is the only significant variable is required to determine whether $\mathrm{K}_{\mathrm{IU}}$ is a materials constant and independent of specimen geometry.

\section{Application to Fatigue Crack Propagation Studies}

Because it is effective when stresses are high and cracks are too small for conventional linear elastic fracture analysis, this method might be useful for low-cycle fatigue crack propagation studies. However, further discussion of this application is beyond the scope of the present report.

\section{CONCLUSIONS}

1. The modified Irwin analysis can be used to predict fracture with reasonable accuracy when crack size and/or material thickness are too small for valid analysis by conventional linear elastic fracture mechanics. The method is usable even when fracture stresses are greater than yield.

2. The weighted-averaging procedure that was used gives a suitable, unambiguous value of the modified toughness parameter $\mathrm{K}_{\mathrm{IU}}$.

3. Systematic tests are required to determine whether the parameter $\mathrm{K}_{\mathrm{IU}}$ is indeed a material constant and independent of material thickness. But, even if it proves not to be, the method would still be useful for specific design problems. 
4. Irwin's fracture equation for through-the-thickness cracks can also be modified to predict fracture at ultimate strength for zero crack length. However, there are not sufficient data for a critical evaluation.

Lewis Research Center,

National Aeronautics and Space Administration, Cleveland, Ohio, May 1, 1969, 124-08-08-19-22.

\section{REFERENCES}

1. Irwin, G. R. : Crack-Extension Force for a Part-Through Crack in a Plate. J. Appl. Mech., vol. 29, no. 4, Dec. 1962, pp. 651-654.

2. Brown, William F., Jr.; and Srawley, John E.: Plane Strain Crack Toughness Testing of High Strength Metallic Materials. Spec. Tech. Publ. No. 410, ASTM, 1967, pp. 30-33.

3. McClintock, F. A.; and Irwin, G. R.: Plasticity Aspects of Fracture Mechanics. Fracture Toughness Testing and Its Applications. Spec. Tech. Publ. No. 381, ASTM, 1965, pp. 84-113.

4. Kobayashi, A. S.: On the Magnification Factors of Deep Surface Flaws. Structural Dev. Res. Memo No. 16, The Boeing Co., Dec. 1965.

5. Smith, F. W.: Stress Intensity Factors for a Semi-Elliptical Surface Flaw. Structural Dev. Res. Memo No. 17, The Boeing Co., Aug. 1966.

6. Wilson, E. Bright, Jr.: An Introduction to Scientific Research. McGraw-Hill Book Co., Inc., 1952, p. 219.

7. ASTM Special Committe on Fracture Testing of High-Strength Metallic Materials:

Fracture Testing of High-Strength Sheet Materials. ASTM Bull. 243. Jan. 1960, pp. 29-40; ASTM Bull. 243, Feb. 1960, pp. 18-28.

8. Hoeppner, David W.; Pettit, Donald E.; Feddersen, Charles E. ; and Hyler, Walter S.: Determination of Flaw Growth Characteristics of Ti-6Al-4V Sheet in the Solution-Treated and Aged Condition. Battelle Memorial Inst. (NASA CR-65811), Jan. 1, 1968.

9. Lewis, R. E.: Fracture Strength of HM21A-T8 Magnesium Alloy Sheet with Simulated Surface Flaws. Lockheed Missiles \& Space Co., Apr. 1965. 
10. Corn, D. L. : Effect of Crack Shape on PTC Fracture Toughness Behavior. Rep. SM-49149, Douglas Aircraft Co., Jan. 5, 1966.

11. Pendleberry, S. L.: Fracture Strength of 6Al-4V Titanium, 5Al-2.5 Sn Titanium, and 2014-T6 Aluminum Sheet Containing Shallow-Cracks at Room Temperature and $-423^{\circ}$ F. Rep. SM-40041, Douglas Aircraft Co., Apr. 2, 1962.

12. Eyring, C. L.: Fracture Strength of 2014-T6 Aluminum Alloy Weldments. Rep. SM-45961, Douglas Aircraft Co., Sept. 1, 1964. 
TABLE I. - SURFACE TEST DATA FROM REFERENCE 8

[Titanium-6AI-4V alloy; solution treated and aged; tested at $70^{\circ}$; ultimate strength (average of three thicknesses and 12 tests), $170.7 \mathrm{ksi}$; yield strength (average of three thicknesses and 11 tests), $161.9 \mathrm{ksi}$; weighted average $K_{1 \mathrm{U}}$ (eq. (6)), $76.5 \mathrm{ksi} \sqrt{\text { in. }] ~}$

\begin{tabular}{|c|c|c|c|c|c|c|c|c|}
\hline \multirow[t]{2}{*}{ Specimen } & \multirow{2}{*}{$\begin{array}{l}\text { Specimen } \\
\text { width, } \\
\text { w, } \\
\text { in. }\end{array}$} & \multirow{2}{*}{$\begin{array}{c}\text { Specimen } \\
\text { thickness, } \\
\text { t, } \\
\text { in. }\end{array}$} & \multirow{2}{*}{$\begin{array}{c}\text { Crack } \\
\text { depth, } \\
\text { a, } \\
\text { in. }\end{array}$} & \multirow{2}{*}{$\begin{array}{c}\text { Crack } \\
\text { length, } \\
2 c \\
\text { in. }\end{array}$} & \multirow{2}{*}{$\begin{array}{c}\text { Fracture } \\
\text { stress, } \\
\sigma, \\
\text { ksi }\end{array}$} & \multirow{2}{*}{$\begin{array}{c}\text { Crack size } \\
\text { factor, } \\
\text { a } / \Phi^{2} \\
\text { in. }\end{array}$} & \multicolumn{2}{|c|}{$\begin{array}{l}\text { Fracture toughness } \\
\text { parameter, ksi } \sqrt{\mathrm{in}} \text {. }\end{array}$} \\
\hline & & & & & & & $\begin{array}{c}\mathrm{K}_{\mathrm{IC}} \\
\text { (a) }\end{array}$ & $\underset{(\mathrm{b})}{\mathrm{K}_{\mathrm{IU}}}$ \\
\hline $2023 N$ & 2. 987 & 0.020 & 0.0131 & 0.0346 & 158.2 & 0.00681 & 26. 80 & 67.49 \\
\hline $2045 \mathrm{~N}$ & 2. 991 & .020 & .0123 & .0279 & 164.7 & .00562 & 25.28 & 91.23 \\
\hline $2025 \mathrm{~N}$ & 2. 994 & .020 & .0169 & .0540 & 155.3 & .01009 & 32.23 & 72.98 \\
\hline $2044 \mathrm{~N}$ & 2.990 & .020 & .0162 & .0390 & 161.5 & .00780 & 29. 22 & 85.52 \\
\hline $2028 \mathrm{E}$ & 2. 990 & .021 & .0051 & .0111 & 158.5 & .00224 & 15. 28 & 39.26 \\
\hline $2003 E$ & 2. 987 & .021 & .0106 & .0428 & 161.9 & .00726 & 28. 98 & 84.53 \\
\hline $2029 \mathrm{E}$ & 2. 988 & .020 & .0102 & .0394 & 157.5 & .00683 & 27. 16 & 65.53 \\
\hline $2043 E$ & 2.988 & .021 & .0151 & .1134 & 153.0 & .01295 & 36.93 & 76.23 \\
\hline $2008 E$ & 2. 992 & .021 & .0190 & .1753 & 148.5 & .01699 & 40. 99 & 76.21 \\
\hline $2015 \mathrm{~N}$ & 2. 991 & .022 & .0077 & .0138 & 162.6 & .00347 & 19. 55 & 61.07 \\
\hline $2037 \mathrm{~N}$ & 2. 997 & .021 & .0120 & .0307 & 162.6 & .00608 & 26.08 & 80.89 \\
\hline $2004 \mathrm{~N}$ & 2.990 & .021 & .0169 & .0451 & 160.9 & .00886 & 31.17 & 88.06 \\
\hline $2035 E$ & 2. 988 & .021 & .0045 & .0114 & 159.3 & .00226 & 15. 54 & 40.94 \\
\hline $4003 \mathrm{~N}$ & 2. 990 & .044 & .0115 & .0300 & 166.8 & .00592 & 26.51 & 117. 26 \\
\hline $4108 \mathrm{~N}$ & 2. 993 & .044 & .0124 & .0288 & 164.8 & .00579 & 25. 70 & 93.40 \\
\hline $4032 \mathrm{~N}$ & 2.991 & .042 & .0229 & .0525 & 161. 2 & .01056 & 33.85 & 97.80 \\
\hline $4088 N$ & 2. 992 & .044 & .0236 & .0605 & 157. 6 & .01198 & 35.35 & 87.18 \\
\hline $4096 \mathrm{~N}$ & 2. 990 & .042 & .0304 & .0820 & 153.7 & .01607 & 39.90 & 86.97 \\
\hline $4104 \mathrm{~N}$ & 2. 992 & .045 & .0355 & .0917 & 154.1 & .01813 & 42.43 & 93.67 \\
\hline $4073 E$ & 2. 992 & .041 & .0088 & .0348 & 167.1 & .00596 & 27. 23 & 122. 65 \\
\hline $4081 E$ & 2. 990 & .042 & .0106 & .0346 & 167.6 & .00642 & 28.08 & 137.44 \\
\hline $4037 \mathrm{E}$ & 2. 992 & .043 & .0207 & .1086 & 154.0 & .01593 & 40.88 & 87. 48 \\
\hline $4077 \mathrm{E}$ & 2. 990 & .044 & .0240 & .1096 & 153.9 & .01744 & 42.54 & 91.23 \\
\hline $4103 \mathrm{E}$ & 2. 992 & .045 & .0345 & .2377 & 137.4 & .02895 & 48.62 & 76.50 \\
\hline $4005 \mathrm{~N}$ & 2. 994 & .045 & .0103 & .0294 & 165.1 & .00568 & 25.79 & 95,14 \\
\hline $4068 \mathrm{~N}$ & 2. 990 & .044 & .0205 & .0597 & 157.2 & .01148 & 34.71 & 83.91 \\
\hline $4051 \mathrm{~N}$ & 2. 993 & .045 & .0343 & .0889 & 152.9 & .01757 & 41.41 & 88.51 \\
\hline $4063 \mathrm{E}$ & 2. 990 & .042 & .0085 & .0365 & 164.4 & .00600 & 26. 90 & 91.90 \\
\hline $4120 \mathrm{E}$ & 2. 992 & .044 & 0234 & .1225 & 153.2 & .01799 & 43.18 & 90.46 \\
\hline $4075 \mathrm{E}$ & 2. 990 & .040 & .0307 & .1976 & 144.3 & .02528 & 48.00 & 83.39 \\
\hline $4094 \mathrm{E}$ & 2. 992 & .042 & .0273 & .2190 & 139.5 & .02376 & 44,94 & 72.44 \\
\hline $6002 N$ & 2. 991 & .064 & 0131 & .0321 & 153.9 & .00641 & 25.12 & 55.28 \\
\hline $6004 \mathrm{~N}$ & 2. 990 & .064 & .0134 & .0343 & 155.0 & .00679 & 26.13 & 59.22 \\
\hline $6001 \mathrm{~N}$ & 2. 991 & .062 & .0269 & .0648 & 148.9 & .01296 & 34.44 & 67.31 \\
\hline $6010 \mathrm{~N}$ & 2. 993 & .064 & .0298 & .0690 & 150.0 & .01387 & 35.85 & 71.86 \\
\hline $6005 \mathrm{~N}$ & 2. 993 & .064 & .0431 & .1021 & 145.1 & .02047 & 42.04 & 76.52 \\
\hline $6025 \mathrm{~N}$ & 2. 994 & .063 & .0435 & .1001 & 146.3 & .02014 & 42.03 & 78.24 \\
\hline $6035 E$ & 2. 994 & .063 & .0165 & .0509 & 153.1 & .00962 & 30.92 & 65.94 \\
\hline $6037 \mathrm{E}$ & 2. 993 & .063 & .0187 & .0548 & 151.8 & .01052 & 31.95 & 66.10 \\
\hline $6038 \mathrm{E}$ & 2. 992 & .064 & .0312 & .1253 & 148.8 & .02132 & 45.03 & 86.08 \\
\hline $6045 E$ & 2. 991 & .063 & .0309 & .1335 & 146.6 & .02189 & 44.98 & 82. 21 \\
\hline $6033 \mathrm{E}$ & 2. 993 & .064 & .0460 & .3470 & 121.1 & .03948 & 49.30 & $c_{66.29}$ \\
\hline $6034 \mathrm{E}$ & 2. 994 & .063 & .0477 & .3544 & 118.6 & .04080 & 48.96 & ${ }^{c} 64.67$ \\
\hline $6011 \mathrm{~N}$ & 2. 992 & .064 & .0138 & .0317 & 154.3 & .00638 & 25.07 & 55.94 \\
\hline $6016 \mathrm{~N}$ & 2. 991 & .064 & .0131 & .0365 & 156.4 & .00710 & 27.08 & 63.87 \\
\hline $6017 \mathrm{~N}$ & 2. 994 & .065 & .0304 & .0694 & 150.0 & .01397 & 35.96 & 72.12 \\
\hline $6018 \mathrm{~N}$ & 2. 994 & .066 & .0317 & .0713 & 149.0 & .01437 & 36.19 & 71.08 \\
\hline $6003 \mathrm{~N}$ & 2. 994 & .065 & .0460 & .1062 & 146.4 & .02136 & 43.32 & .80 .78 \\
\hline $6013 N$ & 2. 987 & .065 & .0453 & .1042 & 143.2 & .02096 & 41.90 & 73.96 \\
\hline $6039 \mathrm{E}$ & 2. 994 & .063 & .0200 & .0573 & 153.0 & .01107 & 33.03 & 70.48 \\
\hline $6036 \mathrm{E}$ & 2. 994 & .062 & .0198 & .0561 & 150.3 & .01087 & 32.07 & 64.17 \\
\hline $6030 \mathrm{E}$ & 2. 994 & .062 & .0315 & .1216 & 147.1 & .02108 & 44.13 & 81.73 \\
\hline $6043 \mathrm{E}$ & 2. 994 & .064 & .0305 & .1226 & 145.6 & .02085 & 43.45 & 78.20 \\
\hline $6022 \mathrm{E}$ & 2. 994 & .063 & .0486 & .3429 & 121.4 & .04104 & 50.35 & $c_{67.92}$ \\
\hline $6041 E$ & 2. 994 & .062 & .0470 & .3470 & 119.9 & .04014 & 49.14 & $c_{65.52}$ \\
\hline
\end{tabular}

${ }_{\mathrm{B}}^{\mathrm{Eq}}$. (1b)

Eq. (2b)

$c_{\text {Excluded from weighted average; see text. }}$ 
TABLE II. - SURFACE CRACK TEST DATA FROM REFERENCE 9

(a) Magnesium alloy HM21A-T8; longitudinal grain; tested at $70^{\circ} \mathrm{F}$. Ultimate strength (average of 12 tests), $34.0 \mathrm{ksi}$; yield strength (average of 12 tests), $23.8 \mathrm{ksi}$; weighted average $\mathrm{K}_{\mathrm{IU}}$ (eq. (6)), $23.7 \mathrm{ksi} \sqrt{\mathrm{in}}$.

\begin{tabular}{|c|c|c|c|c|c|c|c|c|}
\hline \multirow[t]{2}{*}{ Specimen } & \multirow{2}{*}{$\begin{array}{c}\text { Specimen } \\
\text { width, } \\
\text { W, } \\
\text { in. }\end{array}$} & \multirow{2}{*}{$\begin{array}{c}\text { Specimen } \\
\text { thickness, } \\
t \\
\text { in. }\end{array}$} & \multirow{2}{*}{\begin{tabular}{|} 
Crack \\
depth, \\
a, \\
in.
\end{tabular}} & \multirow{2}{*}{\begin{tabular}{|l} 
Crack \\
length, \\
$2 c$ \\
in.
\end{tabular}} & \multirow{2}{*}{$\begin{array}{c}\text { Fracture } \\
\text { stress, } \\
\sigma \\
\text { ksi }\end{array}$} & \multirow{2}{*}{$\begin{array}{c}\text { Crack size } \\
\text { factor } \\
\text { a } / \Phi^{2} \\
\text { in. }\end{array}$} & \multicolumn{2}{|c|}{$\begin{array}{l}\text { Fracture toughness } \\
\text { parameter, ksi } \sqrt{\text { in }}\end{array}$} \\
\hline & & & & & & & $\begin{array}{l}\mathrm{K}_{\mathrm{IC}} \\
(\mathrm{a})\end{array}$ & ${ }_{\text {(b) }}^{\mathrm{K}_{\mathrm{IU}}}$ \\
\hline CL1 & 2. 000 & 0.1428 & 0.042 & 0.433 & 30.742 & 0.03824 & 14. 18 & 27.32 \\
\hline CI_3 & 1. 999 & .1439 & .026 & .404 & 31.978 & .02477 & 12. 26 & 28.77 \\
\hline CL5 & 2.000 & .1445 & .040 & .422 & 31.280 & .03654 & 14. 23 & 29.62 \\
\hline $\mathrm{CL} 7$ & 1. 999 & .1448 & .060 & .420 & 29.706 & .05056 & 15.27 & 26.66 \\
\hline CL 9 & 2.000 & .1450 & .060 & .420 & 29.724 & .05056 & 15.28 & 26.73 \\
\hline CL11 & 1. 999 & .1450 & .062 & .473 & 29.251 & .05335 & 15.42 & 25.74 \\
\hline CL2 & 2. 001 & .1430 & .026 & .282 & 31.667 & .02384 & 11.73 & 26.08 \\
\hline CL4 & 2. 001 & .1442 & .028 & .273 & 32. 166 & .02527 & 12.31 & 30.64 \\
\hline CL6 & 2.001 & .1448 & .032 & .284 & 32. 171 & .02841 & 13.00 & 32.54 \\
\hline $\mathrm{CL} 8$ & 2.001 & .1452 & .024 & .237 & 32.771 & .02170 & 11.75 & 35.18 \\
\hline CL10 & 2.001 & 1455 & .028 & .273 & 32.360 & .02527 & 12.43 & 32.55 \\
\hline CL12 & 2.001 & .1454 & .042 & .332 & 31.488 & .03643 & 14.17 & 30.93 \\
\hline CL13 & 1. 999 & .1455 & .034 & .610 & 31.145 & .03273 & 13.57 & 27.27 \\
\hline CL14 & 2.000 & .1451 & .600 & .600 & 33.425 & .00599 & 6.58 & 27.42 \\
\hline CL15 & 2. 000 & .1455 & .034 & .680 & 30.722 & .03294 & 13.35 & 25.27 \\
\hline $\operatorname{CL} 16$ & 2. 000 & .1450 & .025 & .615 & 31.862 & .02445 & 12. 20 & 27.71 \\
\hline $\mathrm{CLI7}$ & 1.999 & .1455 & .028 & .580 & 31.351 & .02717 & 12.52 & 25.93 \\
\hline CL18 & 2.000 & .1456 & .052 & .640 & 28.091 & .04845 & 14.10 & 21.31 \\
\hline CLI9 & 1. 999 & .1453 & .050 & .626 & 28.916 & .04668 & 14.42 & 23.06 \\
\hline CL2O & 1. 999 & .1455 & .048 & .565 & 29.495 & .04449 & 14.46 & 24.28 \\
\hline HL2 & 3. 951 & .1450 & .048 & .625 & 28.975 & .04500 & 14. 21 & 22.81 \\
\hline HL3 & 3.951 & .1448 & .070 & .820 & 26.744 & .06484 & 15. 25 & 21.41 \\
\hline HLA & 3.951 & .1448 & .068 & .980 & 27.530 & .06438 & 15.86 & 23.11 \\
\hline HL5 & 3.951 & .1439 & .076 & 1.000 & 24.978 & .07133 & 14.66 & $c_{19.09}$ \\
\hline HI 6 & 3. 951 & .1432 & .084 & .970 & 24.214 & .07767 & 14.68 & ${ }^{c_{18.66}}$ \\
\hline HL7 & 3.934 & .1447 & .032 & 1. 520 & 31.096 & .03177 & 13.45 & 26.61 \\
\hline HL8 & 3.933 & .1447 & .074 & 1. 510 & 25.040 & .07176 & 14.82 & $\mathrm{c}_{19.25}$ \\
\hline HL9 & 3. 934 & .1448 & .092 & 1.500 & 20.277 & .08799 & 12.65 & $\mathrm{c}_{14.55}$ \\
\hline HL10 & 3. 934 & .1443 & .086 & 1.500 & 21. 138 & .08264 & 12.88 & ${ }^{c_{15.06}}$ \\
\hline HL11 & 3.934 & .1442 & .083 & 1.500 & 20.800 & .07994 & 12.43 & ${ }^{c}{ }_{14.43}$ \\
\hline HL12 & 3.934 & .1420 & .088 & 1.520 & 20.587 & .08450 & 12. 62 & $c_{14.60}$ \\
\hline FL13 & 1. 998 & .1447 & .036 & .590 & 31.062 & .03444 & 13.84 & 27.53 \\
\hline FL14 & 1. 995 & .1444 & .034 & .580 & 31.378 & .03262 & 13.69 & 28.58 \\
\hline FL15 & 1. 973 & .1442 & .072 & .618 & 26.995 & .06353 & 15.16 & 21.73 \\
\hline FL17 & 1. 973 & .1449 & .064 & .600 & 27.842 & .05739 & 15.06 & 22.56 \\
\hline FL21 & 1. 999 & .1430 & .068 & .740 & 25.883 & .06239 & 14. 31 & 19.36 \\
\hline FL7 & 1. 973 & .1450 & .023 & .424 & 32.517 & .02218 & 11. 96 & 32.19 \\
\hline FL8 & 1. 997 & 1453 & .026 & .400 & 32.047 & .02475 & 12.30 & 29.31 \\
\hline FL9 & 1. 973 & .1449 & .066 & .530 & 28.541 & .05745 & 15.50 & 24.44 \\
\hline FL10 & 1. 972 & .1448 & .038 & .410 & 31.243 & .03482 & 13.88 & 28.70 \\
\hline FL11 & 1. 912 & .1449 & .040 & .840 & 29.458 & .03835 & 13.63 & 22.58 \\
\hline FL12 & 1. 974 & .1447 & .063 & 488 & 28.641 & .05440 & 15.13 & 24.07 \\
\hline FL4 & 1. 973 & 1454 & .023 & 230 & 33.182 & .02084 & 11.75 & 42. 66 \\
\hline FL5 & 1. 912 & .1453 & .024 & .236 & 33. 261 & .02169 & 12.03 & 45.87 \\
\hline FL6 & 1.976 & .1453 & .026 & .235 & 33.022 & .02316 & 12. 23 & 40.98 \\
\hline
\end{tabular}

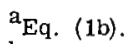

$\mathrm{b}_{\mathrm{Eq} \text {. (2b). }}$

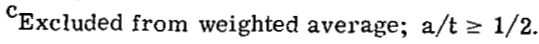


TABLE II. - Concluded. SURFACE CRACK TEST DATA FROM REFERENCE 9

(b) Magnesium alloy HM21A-T8, transverse grain; tested at $70^{\circ} \mathrm{F}$. Ultimate strength (average of 12 tests), $38.0 \mathrm{ksi}$; yield strength (average of 12 tests), $25.5 \mathrm{ksi}$; weighted average $\mathrm{K}_{\mathrm{IU}}$ (eq. (6)), $23.9 \mathrm{ksi} \sqrt{\text { in. }}$

\begin{tabular}{|c|c|c|c|c|c|c|c|c|}
\hline \multirow[t]{2}{*}{ Specimen } & \multirow{2}{*}{$\begin{array}{l}\text { Specimen } \\
\text { width, } \\
\text { w, } \\
\text { in. }\end{array}$} & \multirow{2}{*}{$\begin{array}{c}\text { Specimen } \\
\text { thickness, } \\
t, \\
\text { in. }\end{array}$} & \multirow{2}{*}{$\begin{array}{l}\text { Crack } \\
\text { depth, } \\
\text { a, } \\
\text { in. }\end{array}$} & \multirow{2}{*}{$\begin{array}{l}\text { Crack } \\
\text { length, } \\
2 c,\end{array}$} & \multirow{2}{*}{$\begin{array}{c}\text { Fracture } \\
\text { stress, } \\
\sigma \\
\text { ksi }\end{array}$} & \multirow{2}{*}{$\begin{array}{c}\text { Crack size } \\
\text { factor, } \\
\text { a } / \Phi^{2} \\
\text { in. }\end{array}$} & \multicolumn{2}{|c|}{$\begin{array}{l}\text { Fracture toughness } \\
\text { parameter, ksi } \sqrt{\text { in }}\end{array}$} \\
\hline & & & & & & & $\begin{array}{l}\mathrm{K}_{\mathrm{IC}} \\
\text { (a) }\end{array}$ & $\begin{array}{l}\mathrm{K}_{\mathrm{IU}} \\
\text { (b) }\end{array}$ \\
\hline DT1 & 2. 000 & 0.1457 & 0.054 & 0.435 & 32. 121 & 0.04703 & 16.09 & 25.31 \\
\hline DT3 & 2. 000 & .1457 & .052 & .428 & 32. 258 & .04550 & 15.93 & 25.28 \\
\hline DT5 & 2. 010 & .1457 & .048 & .425 & 32.670 & .04260 & 15.75 & 25.63 \\
\hline DT7 & 2. 000 & .1453 & .062 & .460 & 31.796 & .05301 & 16.77 & 25.96 \\
\hline DT 9 & 2.000 & 1455 & .062 & .451 & 31.478 & .05275 & 16.49 & 25.06 \\
\hline DT11 & 2. 000 & .1455 & .064 & .471 & 31.134 & .05461 & 16.53 & 24.64 \\
\hline DT2 & 2. 000 & .1455 & .033 & .235 & 34.639 & .02793 & 13.75 & 27.34 \\
\hline DT4 & 2. 000 & .1453 & .038 & .272 & 33.930 & .03220 & 14. 32 & 26. 26 \\
\hline DT6 & 2.000 & .1450 & .040 & .278 & 33.862 & .03364 & 14.57 & 26.58 \\
\hline DT8 & 2.000 & .1455 & .038 & .262 & 33.402 & .03190 & 13.90 & 24.29 \\
\hline DT10 & 2.000 & .1452 & .032 & .256 & 34.642 & .02783 & 13.82 & 27.30 \\
\hline DT 13 & 2. 001 & .1456 & .026 & .500 & 34.758 & .02513 & 13. 60 & 26.47 \\
\hline DT14 & 2. 000 & .1451 & .028 & .600 & 34.390 & .02722 & 13.94 & 25. 90 \\
\hline DT 15 & 2. 001 & .1455 & .090 & .596 & 28.787 & .07472 & 17. 35 & $a_{23.41}$ \\
\hline DT 16 & 2.000 & .1450 & .074 & .562 & 30.138 & .06362 & 17. 10 & $\mathrm{a}_{24.23}$ \\
\hline DT 17 & 2. 001 & .1456 & .072 & .605 & 27. 797 & .06326 & 15.38 & 19.91 \\
\hline DT18 & 2. 000 & .1450 & .044 & .660 & 32.345 & .04180 & 15.62 & 24.46 \\
\hline DT20 & 2. 000 & .1451 & .064 & .940 & 29. 152 & .06070 & 16. 24 & 21.74 \\
\hline GT2 & 3.953 & .1442 & .075 & 1.120 & 28.105 & .07123 & 16.76 & $\mathrm{a}_{21.64}$ \\
\hline GT3 & 3.950 & .1442 & .068 & .840 & 30.074 & .06339 & 17. 27 & 24.05 \\
\hline GT4 & 3. 964 & .1444 & .084 & .900 & 27.690 & .07690 & 16.98 & $\mathrm{a}_{21.77}$ \\
\hline GT5 & 3. 964 & .1443 & .088 & 1.000 & 27.400 & .08120 & 17. 23 & $\mathrm{a}_{21.88}$ \\
\hline GT6 & 3. 963 & .1444 & .084 & 1. 080 & 26. 542 & .07865 & 16. 31 & $a_{20.20}$ \\
\hline GT7 & 3.963 & .1450 & .027 & 1.500 & 34.372 & .02685 & 13.93 & 25.65 \\
\hline GT8 & 3.966 & .1450 & .096 & 1. 500 & 24.587 & .09151 & 16.03 & ${ }^{a} 18.94$ \\
\hline GT9 & 3. 964 & .1452 & .092 & 1. 480 & 25.017 & 08790 & 16.05 & ${ }^{\mathrm{a}}{ }_{19.13}$ \\
\hline GT 11 & 3.964 & .1452 & .086 & 1.520 & 24.687 & .08271 & 15.33 & ${ }^{a} 18.13$ \\
\hline GT12 & 3. 963 & .1453 & .0902 & 1. 590 & 22.803 & .08673 & 14. 25 & ${ }^{a} 16.30$ \\
\hline FT13 & 1. 999 & .1440 & .010 & .608 & 36.425 & .00995 & 9.35 & 24.77 \\
\hline FT 14 & 1. 9997 & .1442 & .010 & 600 & 37,226 & .00995 & 9.72 & 35.91 \\
\hline FT15 & 2. 000 & .1439 & .060 & 545 & 32.097 & .05350 & 17. 23 & 26.93 \\
\hline FT16 & 1. 912 & .1437 & .070 & 580 & 29.985 & .06133 & 16.73 & 23.47 \\
\hline FT17 & 1. 997 & .1441 & .069 & 820 & 27.415 & .06403 & 15.32 & 19.45 \\
\hline FT18 & 1. 997 & .1444 & .074 & 600 & 30. 166 & .06454 & 17. 29 & $a_{24.47}$ \\
\hline FT7 & 1. 972 & .1449 & .016 & .378 & 35.562 & .01562 & 11.17 & 24.49 \\
\hline FT8 & 1. 972 & .1448 & .030 & .394 & 35.447 & .02815 & 14.72 & 32.05 \\
\hline FT9 & 1. 998 & .1450 & .046 & .385 & 33.414 & .04038 & 15.81 & 27. 38 \\
\hline FT10 & 1. 999 & .1450 & .038 & .517 & 33.460 & .03578 & 15.17 & 25. 93 \\
\hline FT11 & 1. 912 & .1448 & .055 & .402 & 32.575 & .04685 & 16. 30 & 26.59 \\
\hline FT12 & 1. 974 & .1449 & .052 & .400 & 33. 217 & .04483 & 16. 44 & 28.12 \\
\hline FT4 & 1. 999 & .1452 & .028 & 200 & 35.687 & .02372 & 13.26 & 31.06 \\
\hline FT5 & 1. 999 & .1450 & .028 & .232 & 35.461 & .02453 & 13.47 & 30.01 \\
\hline FT6 & 1. 998 & .1450 & .034 & .254 & 35.197 & .02912 & 14.42 & 30.94 \\
\hline
\end{tabular}

${ }^{\mathrm{a}}$ Eq. (1b).

bq. (2b).

$c_{\text {Excluded from weighted average; } a / t} \geq 1 / 2$. 
TABLE II. - SURFACE CRACK TEST DATA FROM REFERENCE 10

[Specimen width, 1.0 in.]

(a) Aluminum alloy 2014-T651; tested at $-423^{\circ} \mathrm{F}$. Ultimate strength (average of two tests), $94.5 \mathrm{ksi}$; yield strength (estimated, no test reported), $81.9 \mathrm{ksi}$; weighted average $\mathrm{K}_{\mathrm{IU}}$ (eq. (6)), $52.5 \mathrm{ksi} \sqrt{\mathrm{in}}$; specimen thickness, 0.375 inch

\begin{tabular}{|c|c|c|c|c|c|c|}
\hline \multirow[t]{2}{*}{ Specimen } & \multirow{2}{*}{$\begin{array}{l}\text { Crack } \\
\text { depth, } \\
\text { a, } \\
\text { in. }\end{array}$} & \multirow{2}{*}{$\begin{array}{l}\text { Crack } \\
\text { length, } \\
2 \mathrm{c}, \\
\text { in. }\end{array}$} & \multirow{2}{*}{$\begin{array}{c}\text { Fracture } \\
\text { stress, } \\
\sigma \\
\text { ksi }\end{array}$} & \multirow{2}{*}{$\begin{array}{c}\text { Crack size } \\
\text { factor, } \\
\text { a } / \Phi^{2} \\
\text { in. }\end{array}$} & \multicolumn{2}{|c|}{$\begin{array}{l}\text { Fracture toughness } \\
\text { parameter, ksi } \sqrt{\text { in. }}\end{array}$} \\
\hline & & & & & ${ }_{\text {(a) }}^{\mathrm{K}_{\mathrm{IC}}}$ & $\mathrm{K}_{\text {(b) }}$ \\
\hline 11 & 0.008 & 0.012 & 93.7 & 0.00419 & 12.74 & 93.65 \\
\hline 12 & .019 & .037 & 87.1 & .00791 & 15.85 & 38.88 \\
\hline 3 & .030 & .065 & 85.0 & .01314 & 19.94 & 43.39 \\
\hline 13 & .031 & .061 & 84.4 & .01277 & 19.44 & 41.25 \\
\hline 4 & .052 & .123 & 81.3 & .02466 & 26.12 & 48.71 \\
\hline 5 & .074 & .185 & 79.5 & .03680 & 31.20 & 54.84 \\
\hline 15 & .081 & .147 & 79.8 & .03605 & 30.83 & 54.99 \\
\hline 6 & .084 & .239 & 77.7 & .04625 & 34.30 & 57.07 \\
\hline 16 & .090 & .189 & 78.0 & .03827 & 30.92 & 52.54 \\
\hline 17 & .092 & .190 & 75.3 & .03849 & 29.82 & 47.52 \\
\hline 20 & .096 & .203 & 78.0 & .04109 & 32.05 & 54.44 \\
\hline 7 & .104 & .311 & 74.0 & .05936 & 36.88 & 56.33 \\
\hline 8 & .117 & .365 & 71.7 & .06877 & 38.39 & 56.08 \\
\hline 9 & .129 & .423 & 67.7 & .07836 & 38.53 & 52.77 \\
\hline 10 & .139 & .482 & 64.5 & .08744 & 38.67 & 50.69 \\
\hline
\end{tabular}

(b) 4340 alloy steel; tempered at $475^{\circ} \mathrm{F}$ for 2 hours; tested at $70^{\circ} \mathrm{F}$. Ultimate strength (average of two tests), $278.4 \mathrm{ksi}$; yield strength (number of tests not reported), $230.6 \mathrm{ksi}$; weighted average $\mathrm{K}_{\mathrm{IU}}$ (eq. (6)), $70.2 \mathrm{ksi} \sqrt{\mathrm{in}}$.; specimen thickness, 0.25 inch

\begin{tabular}{|r|r|r|r|r|r|r|}
\hline 3 & 0.020 & 0.041 & 245.5 & 0.00831 & 45.79 & 92.12 \\
8 & .035 & .092 & 205.9 & .01813 & 56.36 & 79.98 \\
9 & .037 & .088 & 201.1 & .01763 & 53.97 & 74.98 \\
12 & .039 & .124 & 183.8 & .02322 & 56.70 & 72.40 \\
11 & .040 & .129 & 173.9 & .02404 & 54.36 & 67.03 \\
15 & .049 & .156 & 174.3 & .02920 & 60.03 & 74.16 \\
14 & .051 & .170 & 158.7 & .03131 & 56.28 & 66.36 \\
18 & .052 & .198 & 158.0 & .03453 & 58.99 & 69.24 \\
16 & .053 & .161 & 164.1 & .03059 & 57.54 & 68.98 \\
19 & .056 & .208 & 154.7 & .03668 & 59.41 & 69.19 \\
13 & .058 & .127 & 174.8 & .02566 & 55.89 & 69.85 \\
20 & .077 & .211 & 148.4 & .04121 & 59.92 & 69.13 \\
\hline
\end{tabular}

$\mathrm{a}_{\mathrm{Eq}} .(1 \mathrm{~b})$.

$\mathrm{b}_{\mathrm{Eq} .}$ (2b). 
[Specimen width, 1.0 in. $(2.54 \mathrm{~cm})$.

(a) Aluminum alloy 2014-T6; tested at $70^{\circ} \mathrm{F}$. Ultimate strength (one test), $72.1 \mathrm{ksi}$; yield strength (one test), $67.0 \mathrm{ksi}$; weighted average $\mathrm{K}_{\mathrm{IU}}$ (eq. (6)), $40.3 \mathrm{ksi} \sqrt{\mathrm{in}}$.; specimen thickness, 0.10 inch

\begin{tabular}{|c|c|c|c|c|c|c|}
\hline \multirow[t]{2}{*}{ Specimen } & \multirow{2}{*}{$\begin{array}{c}\text { Crack } \\
\text { depth, } \\
\text { a, } \\
\text { in. }\end{array}$} & \multirow{2}{*}{$\begin{array}{c}\text { Crack } \\
\text { length, } \\
2 \mathrm{c}, \\
\text { in. }\end{array}$} & \multirow{2}{*}{$\begin{array}{c}\text { Fracture } \\
\text { stress, } \\
\sigma, \\
\text { ksi }\end{array}$} & \multirow{2}{*}{$\begin{array}{c}\text { Crack size } \\
\text { factor, } \\
\text { a } / \Phi^{2} \\
\text { in. }\end{array}$} & \multicolumn{2}{|c|}{$\begin{array}{l}\text { Fracture toughness } \\
\text { parameter, ksi } \sqrt{\text { in. }}\end{array}$} \\
\hline & & & & & $\begin{array}{l}\mathrm{K}_{\mathrm{IC}} \\
\text { (a) }\end{array}$ & $\begin{array}{c}\mathrm{K}_{\mathrm{IU}} \\
\text { (b) }\end{array}$ \\
\hline A 15 & 0.019 & 0.043 & 69.870 & 0.00866 & 13.35 & 51.28 \\
\hline A 14 & .024 & .049 & 68.870 & .00993 & 13.99 & 45.08 \\
\hline A 17 & 025 & .046 & 69.240 & .01098 & 14.85 & 50.61 \\
\hline A 16 & 034 & .065 & 66.880 & .01440 & 16.33 & 41. 76 \\
\hline A 19 & 039 & .094 & 64.450 & .01880 & 18.03 & 38.30 \\
\hline A18 & .046 & .108 & 63.895 & .02168 & 19.16 & 39.44 \\
\hline A 20 & .047 & 198 & 61.150 & .03290 & 23.00 & 40.66 \\
\hline A21 & .049 & .150 & 61.930 & .02843 & 21.43 & 39.61 \\
\hline A 22 & .050 & .189 & 59.345 & .03307 & 22. 21 & $\mathbf{c}_{36.91}$ \\
\hline
\end{tabular}

(b) Aluminum alloy 2014-T6; tested at $-423^{\circ} \mathrm{F}$. Ultimate strength (two tests), $99.7 \mathrm{ksi}$; yield strength (estimated, no test reported), $78.5 \mathrm{ksi}$; weighted average $\mathrm{K}_{\mathrm{IU}}$ (eq. (6)), $36.4 \mathrm{ksi} \sqrt{\mathrm{in}}$; specimen thickness, 0.10 inch

\begin{tabular}{|l|r|r|r|r|r|r|} 
A1 & 0.005 & 0.010 & 98.300 & 0.00203 & 9.24 & 51.36 \\
A2 & .009 & .018 & 95.935 & .00365 & 12.05 & 41.30 \\
A3 & .015 & .030 & 91.360 & .00608 & 14.71 & 34.54 \\
A4 & .019 & .040 & 88.715 & .00810 & 16.48 & 33.96 \\
A5 & .021 & .045 & 87.490 & .00910 & 17.22 & 33.79 \\
A6 & .025 & .058 & 85.340 & .01166 & 19.04 & 34.60 \\
A7 & .030 & .069 & 83.985 & .01388 & 20.39 & 35.65 \\
A8 & .033 & .080 & 82.105 & .01599 & 21.40 & 35.53 \\
A9 & .034 & .080 & 82.445 & .01605 & 21.50 & 36.06 \\
A10 & .038 & .078 & 82.670 & .01580 & 21.24 & 36.09 \\
A11 & .042 & .120 & 78.245 & .02320 & 24.62 & 37.33 \\
A12 & .048 & .145 & 76.265 & .02759 & 26.15 & 38.19 \\
\hline
\end{tabular}

${ }^{\mathrm{a}} \mathrm{Eq} .(1 \mathrm{~b})$.

bq. (2b).

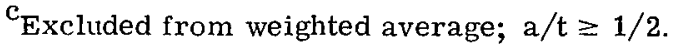


TABLE IV. - Concluded. SURFACE CRACK TEST

\section{DATA FROM REFERENCE 11}

(c) Aluminum alloy 2014-T6; tested at $70^{\circ} \mathrm{F}$. Ultimate strength (one test), $70.3 \mathrm{ksi}$; yield strength (one test), $62.7 \mathrm{ksi}$; weighted average $\mathrm{K}_{\mathrm{IU}}$ (eq. (6)), $43.2 \mathrm{ksi} \sqrt{\mathrm{in}}$; specimen thickness, 0.25 inch

\begin{tabular}{|c|c|c|c|c|c|c|}
\hline \multirow[t]{2}{*}{ Specimen } & \multirow{2}{*}{$\begin{array}{l}\text { Crack } \\
\text { depth, } \\
\text { a, } \\
\text { in. }\end{array}$} & \multirow{2}{*}{$\begin{array}{l}\text { Crack } \\
\text { length, } \\
2 \mathrm{c}, \\
\text { in. }\end{array}$} & \multirow{2}{*}{$\begin{array}{c}\text { Fracture } \\
\text { stress, } \\
\sigma, \\
\text { ksi }\end{array}$} & \multirow{2}{*}{$\begin{array}{l}\text { Crack size } \\
\text { factor, } \\
\text { a } / \Phi^{2} \\
\text { in. }\end{array}$} & \multicolumn{2}{|c|}{$\begin{array}{l}\text { Fracture toughness } \\
\text { parameter, ksi } \sqrt{\text { in }}\end{array}$} \\
\hline & & & & & $\underset{\text { (a) }}{\mathrm{K}_{\mathrm{IC}}}$ & ${ }_{(\mathrm{I})}^{\mathrm{K}_{\mathrm{IU}}}$ \\
\hline AT16 & 0.012 & 0.025 & 71.380 & 0.00506 & 10.49 & (d) \\
\hline AT17 & .025 & .050 & 68.680 & .01013 & 14.18 & 63.85 \\
\hline AT18 & .035 & .080 & 66.840 & .01610 & 17.47 & 53.51 \\
\hline AT 19 & .052 & .120 & 65.160 & .02413 & 20.79 & 52.59 \\
\hline AT20 & .079 & .200 & 60.770 & .03970 & 24.78 & 46.86 \\
\hline $\mathrm{AT} 21$ & .097 & .310 & 54.550 & .05794 & 26.82 & 40.46 \\
\hline AT22 & .125 & .650 & 41.850 & .09587 & 26.13 & $c_{31.32}$ \\
\hline
\end{tabular}

(d) Aluminum alloy 2014-T6; tested at $-423^{\circ} \mathrm{F}$. Ultimate strength (one test), $91.5 \mathrm{ksi}$; yield strength (estimated, no test reported),

$72.0 \mathrm{ksi}$; weighted average $\mathrm{K}_{\mathrm{IU}}$ (eq. (6)), $52.2 \mathrm{ksi} \sqrt{\mathrm{in}}$. ; specimen thickness, 0.25 inch

\begin{tabular}{|l|r|r|r|r|r|r|}
\hline AT1 & 0.005 & 0.010 & 90.500 & 0.00203 & 8.51 & 53.65 \\
AT3 & .020 & .043 & 87.880 & .00870 & 17.13 & 57.14 \\
AT4 & .023 & .047 & 86.710 & .00952 & 17.59 & 51.45 \\
AT2 & .025 & .061 & 86.510 & .01218 & 20.10 & 56.91 \\
AT5 & .026 & .054 & 86.305 & .01094 & 18.77 & 52.76 \\
AT6 & .028 & .060 & 85.980 & .01214 & 19.73 & 53.76 \\
AT7 & .030 & .063 & 85.225 & .01276 & 19.99 & 51.35 \\
AT8 & .039 & .086 & 84.055 & .01737 & 23.04 & 54.43 \\
AT10 & .047 & .099 & 82.040 & .02004 & 24.00 & 50.92 \\
AT9 & .049 & .103 & 81.950 & .02085 & 24.45 & 51.66 \\
AT11 & .054 & .131 & 79.815 & .02618 & 26.83 & 51.28 \\
AT12 & .056 & .145 & 79.035 & .02866 & 27.87 & 51.56 \\
AT13 & .072 & .202 & 76.020 & .03923 & 31.32 & 52.53 \\
\hline
\end{tabular}

\footnotetext{
$\mathrm{a}_{\mathrm{Eq}}$. (1b) .

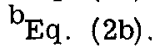

$c_{\text {Excluded from weighted average; } a / t} \geq 1 / 2$.

${ }^{d}$ Cannot be computed; $\sigma \geq \sigma_{\mathrm{u}}$.
} 
TABLE V. - SURFACE CRACK TEST DATA FROM REFERENCE 12 .

$$
\text { [Specimen thickness, } 0.25 \text { in.] }
$$

(a) Aluminum alloy 2014-T6 parent metal; tested at $70^{\circ} \mathrm{F}$. Ultimate strength (average of three tests), $72.1 \mathrm{ksi}$; yield strength

(average of three tests), $63.6 \mathrm{ksi}$; weighted average

$$
\mathrm{K}_{\mathrm{IU}} \text { (eq. (6)), } 54.9 \mathrm{ksi} \sqrt{\mathrm{in} .}
$$

\begin{tabular}{|c|c|c|c|c|c|c|}
\hline \multirow{2}{*}{$\begin{array}{l}\text { Specimen } \\
\text { width, } \\
\text { W, } \\
\text { in. }\end{array}$} & \multirow{2}{*}{$\begin{array}{l}\text { Crack } \\
\text { depth, } \\
\text { a, } \\
\text { in. }\end{array}$} & \multirow{2}{*}{$\begin{array}{l}\text { Crack } \\
\text { length, } \\
2 c \text {, } \\
\text { in. }\end{array}$} & \multirow{2}{*}{$\begin{array}{c}\text { Fracture } \\
\text { stress, } \\
\sigma, \\
\text { ksi }\end{array}$} & \multirow{2}{*}{$\begin{array}{c}\text { Crack size } \\
\text { factor, } \\
\text { a } / \Phi^{2} \\
\text { in. }\end{array}$} & \multicolumn{2}{|c|}{$\begin{array}{l}\text { Fracture toughness } \\
\text { parameter, ksi } \sqrt{\text { in. }}\end{array}$} \\
\hline & & & & & $\underset{\text { (a) }}{\mathrm{K}_{\mathrm{IC}}}$ & ${ }_{(b)}^{K_{I U}}$ \\
\hline \multirow[t]{10}{*}{0.75} & 0.010 & 0.021 & 71.2 & 0.00425 & 9.57 & 58.19 \\
\hline & .020 & .043 & 71.5 & .00870 & 13.77 & 103. 14 \\
\hline & .031 & .061 & 70.9 & .01277 & 16.47 & 86.68 \\
\hline & .039 & .082 & 68.4 & .01660 & 18.08 & 54. 31 \\
\hline & .044 & .100 & 68.2 & .02014 & 19.93 & 58.13 \\
\hline & .058 & .120 & 65.8 & .02431 & 20.94 & 48.82 \\
\hline & .062 & .150 & 65.6 & .02999 & 23.36 & 53. 26 \\
\hline & .063 & .173 & 65.7 & .03377 & 25.00 & 57.03 \\
\hline & .070 & .219 & 63.8 & .04122 & 26.89 & 54.07 \\
\hline & .071 & .189 & 64.8 & .03715 & 25.78 & 55.41 \\
\hline \multirow[t]{5}{*}{1.00} & .023 & .040 & 71.40 & .01064 & 15.27 & 105.12 \\
\hline & .048 & .080 & 68.9 & .02306 & 21.64 & 69.25 \\
\hline & .050 & .127 & 67.2 & .02519 & 22.06 & 57.31 \\
\hline & .065 & .173 & 64.5 & .03401 & 24.53 & 51.77 \\
\hline & .074 & .219 & 64.3 & .04193 & 27.29 & 56.60 \\
\hline
\end{tabular}

(b) Aluminum alloy 2014-T6 parent metal; tested at $-423^{\circ} \mathrm{F}$. Ultimate strength (average of three tests), $98.7 \mathrm{ksi}$; yield strength (estimated, no test reported), $80.0 \mathrm{ksi}$; weighted average $\mathrm{K}_{\mathrm{IU}}$ (eq. (6)), $46.7 \mathrm{ksi} \sqrt{\mathrm{in}}$.

\begin{tabular}{l|l|l|l|l|l|l}
0.75 & 0.010 & 0.020 & 96.6 & 0.00405 & 12.77 & 57.80 \\
.018 & .036 & 92.3 & .00730 & 16.27 & 43.12 \\
.021 & .044 & 90.8 & .00891 & 17.70 & 42.38 \\
.0260 & .058 & 88.8 & .01170 & 19.85 & 42.67 \\
.0390 & .079 & 86.7 & .01601 & 22.48 & 44.52 \\
.0440 & .100 & 84.1 & .02014 & 24.53 & 44.24 \\
.0520 & .124 & 82.6 & .02484 & 26.76 & 46.14 \\
.0620 & .152 & 80.3 & .03033 & 28.69 & 46.67 \\
.0660 & .168 & 78.9 & .03331 & 29.54 & 46.51 \\
.0720 & .201 & 77.9 & .03908 & 31.68 & 48.67 \\
.0720 & .208 & 77.2 & .04009 & 31.81 & 48.15 \\
\hline
\end{tabular}

$a_{\text {Eq. (1b) . }}$

$\mathrm{b}_{\mathrm{Eq}}$. (2b). 
TABLE V. - Continued. SURFACE CRACK TEST

\section{DATA FROM REFERENCE 12}

[Specimen thickness, 0.25 in.]

(c) Aluminum alloy 2014-T6 weldments (4043 filler); tested at $70^{\circ} \mathrm{F}$. Ultimate strength (average of two tests), $42.4 \mathrm{ksi}$; yield strength (average of two tests), $31.9 \mathrm{ksi}$; weighted average $\mathrm{K}_{\mathrm{IU}}$ (eq. (6)), $17.9 \mathrm{ksi} \sqrt{\mathrm{in}}$.

\begin{tabular}{|c|c|c|c|c|c|c|}
\hline \multirow{2}{*}{$\begin{array}{l}\text { Specimen } \\
\text { width, } \\
\text { W, } \\
\text { in. }\end{array}$} & \multirow{2}{*}{$\begin{array}{l}\text { Crack } \\
\text { depth, } \\
\text { a, } \\
\text { in, }\end{array}$} & \multirow{2}{*}{$\begin{array}{l}\text { Crack } \\
\text { length, } \\
2 \mathrm{c}, \\
\text { in. }\end{array}$} & \multirow{2}{*}{$\begin{array}{c}\text { Fracture } \\
\text { stress, } \\
\sigma \\
\text { ksi }\end{array}$} & \multirow{2}{*}{$\begin{array}{c}\text { Crack size } \\
\text { factor, } \\
\text { a } / \Phi^{2} \\
\text { in. }\end{array}$} & \multicolumn{2}{|c|}{$\begin{array}{l}\text { Fracture toughness } \\
\text { parameter, ksi } \sqrt{\mathrm{in}} .\end{array}$} \\
\hline & & & & & $\begin{array}{l}\mathrm{K}_{\mathrm{IC}} \\
\text { (a) }\end{array}$ & ${ }_{(\mathrm{I})}^{\mathrm{K}_{\mathrm{IU}}}$ \\
\hline \multirow[t]{7}{*}{0.75} & 0.025 & 0.042 & 43.0 & 0.01193 & 10.10 & (c) \\
\hline & .053 & .150 & 35.4 & .02907 & 12.66 & 21.35 \\
\hline & .065 & .155 & 34.0 & .03105 & 12.37 & 19.51 \\
\hline & .069 & .173 & 32.0 & .03439 & 12. 19 & 17.59 \\
\hline & .074 & .327 & 27.7 & .05299 & 13.16 & 16.37 \\
\hline & .088 & .234 & 31.4 & .04601 & 13.84 & 19.49 \\
\hline & .095 & .208 & 30.2 & .04202 & 12.56 & 17.15 \\
\hline
\end{tabular}

(d) Aluminum alloy 2014-T6 weldments (4043 filler); tested at $-423^{\circ}$ F. Ultimate strength (average of two tests), $54.0 \mathrm{ksi}$; yield strength (average of two tests), $49.0 \mathrm{ksi}$; weighted average $\mathrm{K}_{\mathrm{IU}}$ (eq. (6)), $26.6 \mathrm{ksi} \sqrt{\mathrm{in}}$.

\begin{tabular}{|l|r|r|r|r|r|r|}
\hline 0.75 & 0.035 & 0.080 & 50.1 & 0.01610 & 13.03 & 33.08 \\
& .058 & .157 & 45.2 & .03075 & 16.18 & 28.13 \\
& .081 & .208 & 42.0 & .04118 & 17.25 & 26.33 \\
& .100 & .250 & 40.0 & .04973 & 17.96 & 25.78 \\
\hline
\end{tabular}

${ }^{\mathrm{a}} \mathrm{Eq} .(1 \mathrm{~b})$.

$b_{\text {Eq. (2b) . }}$

${ }^{\mathrm{c}}$ Cannot be computed; $\sigma \geq \sigma_{\mathrm{u}}$. 
TABLE V. - Concluded. SURFACE CRACK TEST

DATA FROM REFERENCE 12

[Specimen thickness, 0.25 in.]

(e) Aluminum alloy 2014-T6 weldments (716 filler); tested at $70^{\circ} \mathrm{F}$. Ultimate strength (average of four tests), $46.2 \mathrm{ksi}$; yield strength (average of four tests), $36.7 \mathrm{ksi}$; weighted average $\mathrm{K}_{\mathrm{IU}}$ (eq. (6)), $15.6 \mathrm{ksi} \sqrt{\mathrm{in}}$.

\begin{tabular}{|c|c|c|c|c|c|c|}
\hline \multirow{2}{*}{$\begin{array}{l}\text { Specimen } \\
\text { width, } \\
\text { w, } \\
\text { in. }\end{array}$} & \multirow{2}{*}{$\begin{array}{c}\text { Crack } \\
\text { depth, } \\
\text { a, } \\
\text { in. }\end{array}$} & \multirow{2}{*}{$\begin{array}{l}\text { Crack } \\
\text { length, } \\
2 \mathrm{c}, \\
\text { in. }\end{array}$} & \multirow{2}{*}{$\begin{array}{c}\text { Fracture } \\
\text { stress, } \\
\sigma, \\
\text { ksi }\end{array}$} & \multirow{2}{*}{$\begin{array}{c}\text { Crack size } \\
\text { factor, } \\
\text { a } / \Phi^{2} \\
\text { in. }\end{array}$} & \multicolumn{2}{|c|}{$\begin{array}{l}\text { Fracture toughness } \\
\text { parameter, ksi } \sqrt{\mathrm{in}} \text {. }\end{array}$} \\
\hline & & & & & $\underset{\text { (a) }}{\mathrm{K}_{\mathrm{IC}}}$ & ${ }_{(\mathrm{b})}^{\mathrm{K}}$ \\
\hline 0.75 & 0.028 & 0.060 & 40.0 & 0.01214 & 9.17 & 17.78 \\
\hline & .030 & 064 & 37.6 & .01295 & 8.74 & 14. 28 \\
\hline & .046 & 101 & 36.5 & .02040 & 10.63 & 16.49 \\
\hline & .054 & .185 & 31.1 & .03372 & 11. 66 & 14. 99 \\
\hline & .057 & .127 & 32.4 & .02562 & 10.47 & 14. 12 \\
\hline & .062 & .169 & 31.9 & .03305 & 11.77 & 15.56 \\
\hline & .074 & 192 & 31.2 & .03794 & 12. 29 & 15.99 \\
\hline & .074 & .199 & 30.5 & .03903 & 12. 18 & 15.57 \\
\hline & .082 & .263 & 29.4 & .04910 & 13. 20 & 16. 39 \\
\hline
\end{tabular}

(f) Aluminum alloy 2014-T6 weldments (716 filler); tested at $-423^{\circ} \mathrm{F}$. Ultimate strength (average of two tests), $59.5 \mathrm{ksi}$; yield strength (average of two tests), $55.5 \mathrm{ksi}$; weighted average $\mathrm{K}_{\mathrm{IU}}$ (eq. (6)), $17.0 \mathrm{ksi} \sqrt{\mathrm{in}}$.

0.75

\begin{tabular}{|l|l|}
0.014 & 0.029 \\
.018 & .036 \\
.027 & .054 \\
.030 & .070 \\
.044 & .090 \\
.047 & .118 \\
.058 & .139 \\
.062 & .162 \\
.074 & .185 \\
.079 & .203 \\
.081 & .219
\end{tabular}

53.9

54.1

47. 4

49. 9

45. 6

39. 9

38.3

38.6

35. 7

31.9

32.6

0.00587
.00730
.01094
.01406
.01823
.02345
.02782
.03197
.03680
.04018
.04290

8. 38

9. 36

9. 94

11. 98

12. 33

12. 20

12. 72

13. 77

13. 60

12. 64

13.37
18. 94

21. 55

15.93

21. 09

18. 61

15. 99

16. 21

17. 61

16. 62

14. 71

15. 67

$\mathrm{a}_{\mathrm{Eq}}$. (1b).

bq. (2b). 

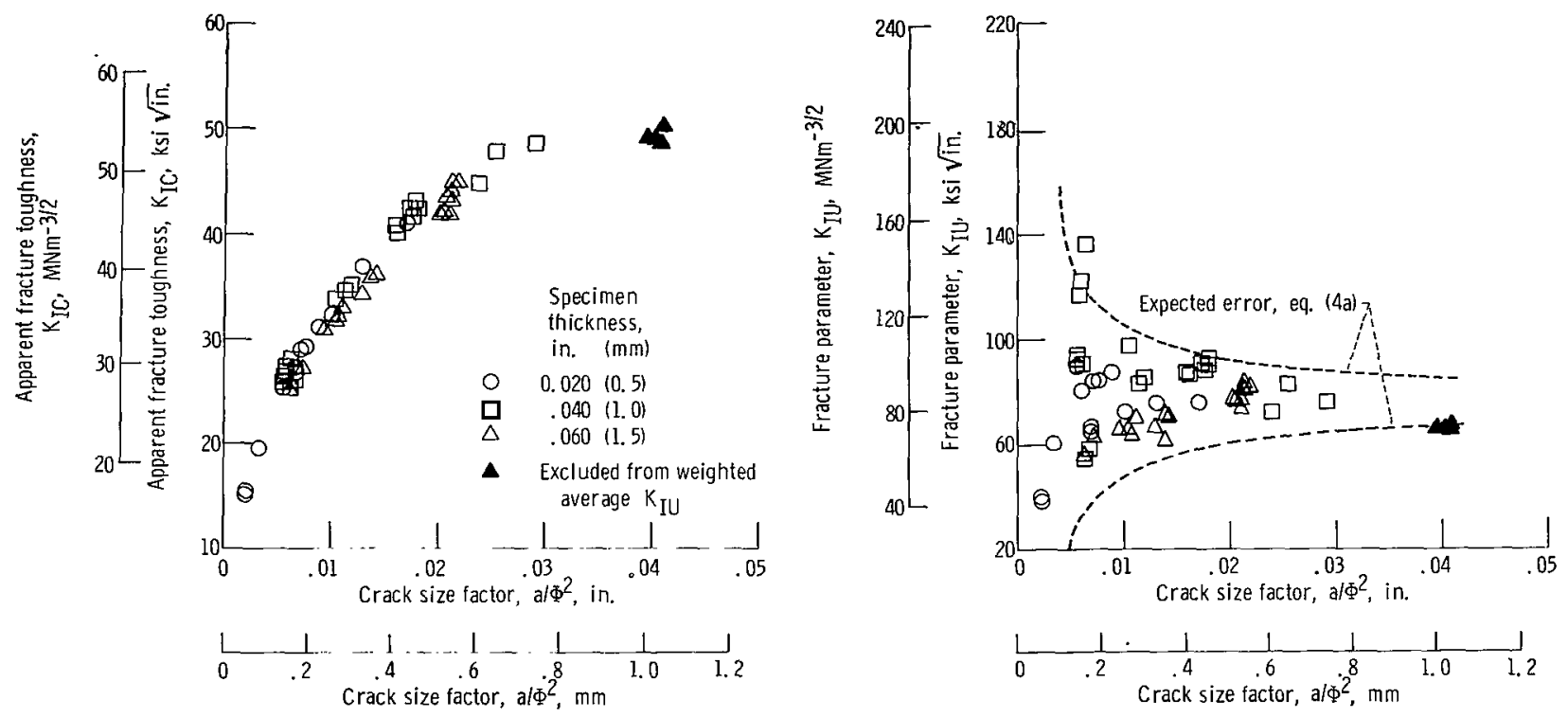

(a) Variation of apparent fracture toughness ( $\mathrm{K}_{\mathrm{IC}}$ ) with crack size.

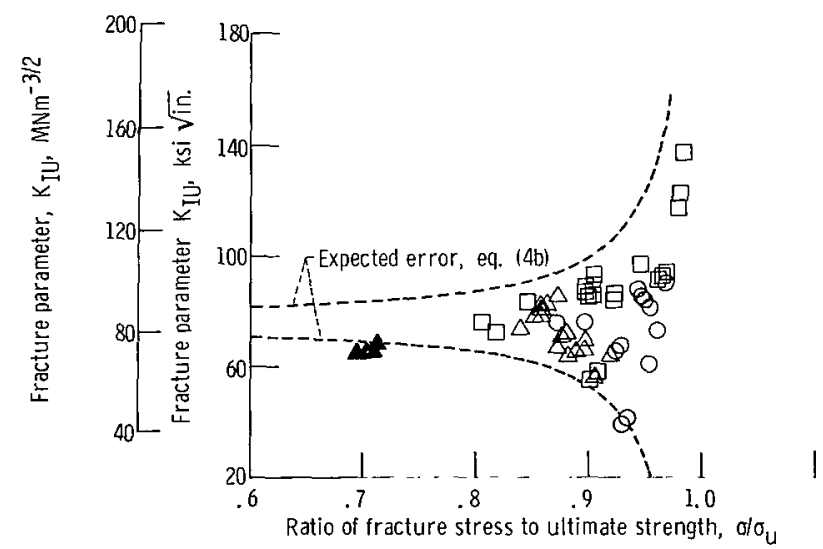

(b) Distribution of $\mathrm{K}_{\mathrm{IU}}$ values as function of crack size factor.
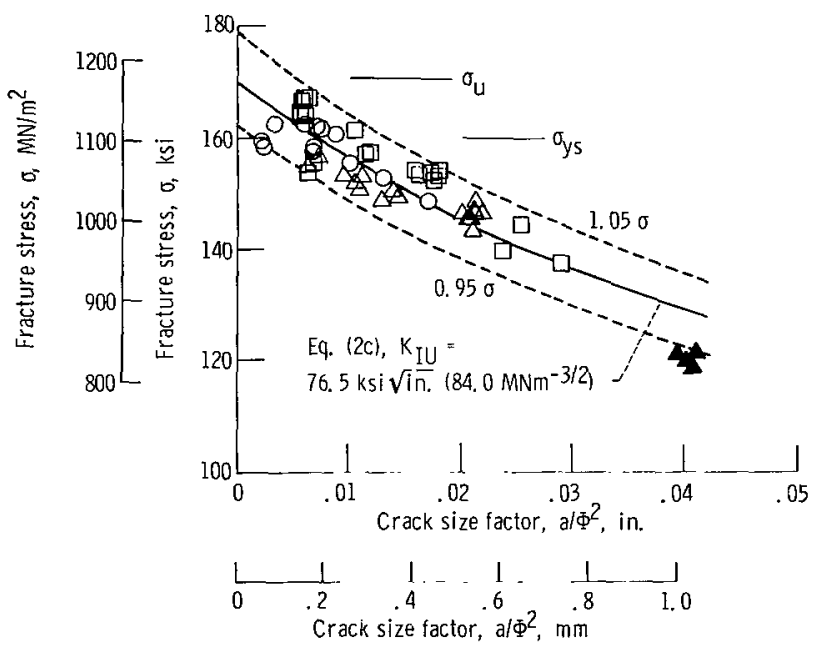

(c) Distribution of $K_{\text {IU }}$ values as function of fracture stress ratio.

(d) Fracture stress as function of crack size factor.

Figure 1. - Fracture parameters for titanium -6Al-4V alloy, solution-treated and aged (data from ref. 8 ). 


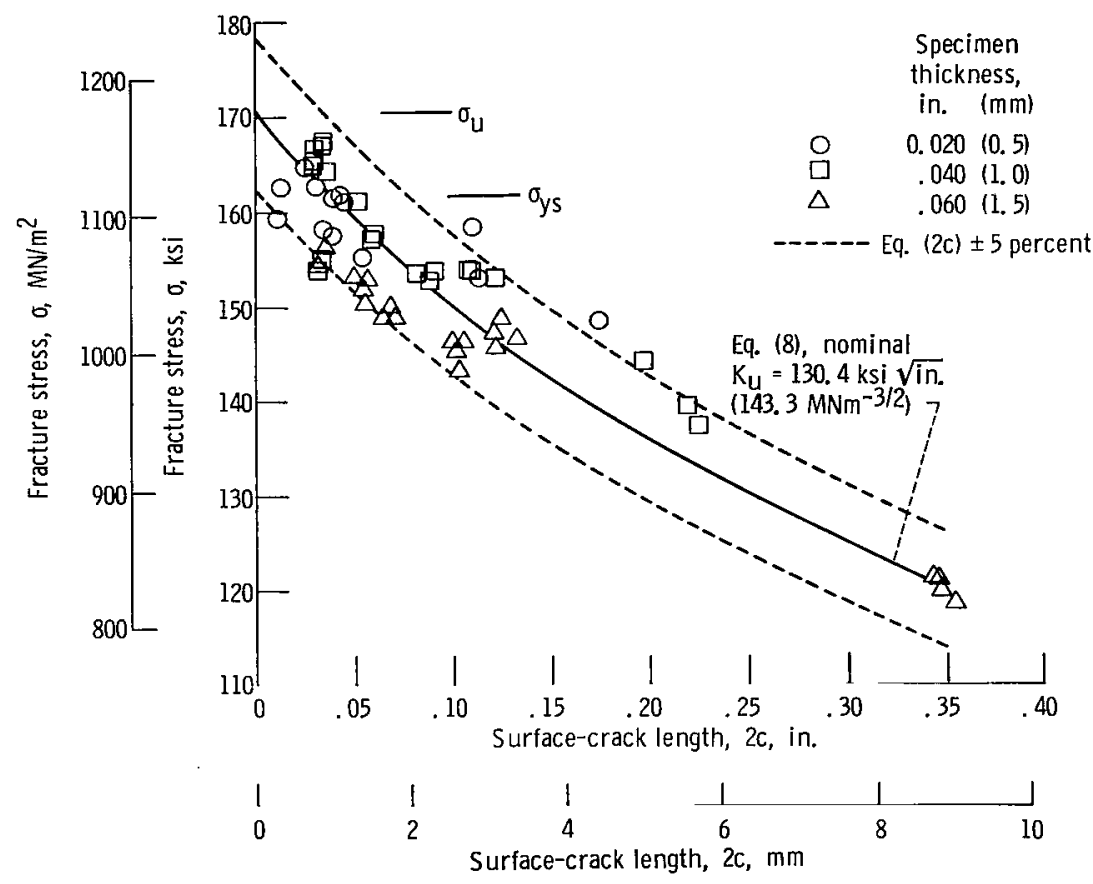

Figure 2. - Correlation between fracture stress and surface-crack length for titanium-6Al-4V alloy, solution treated and aged (data from ref. 8). 


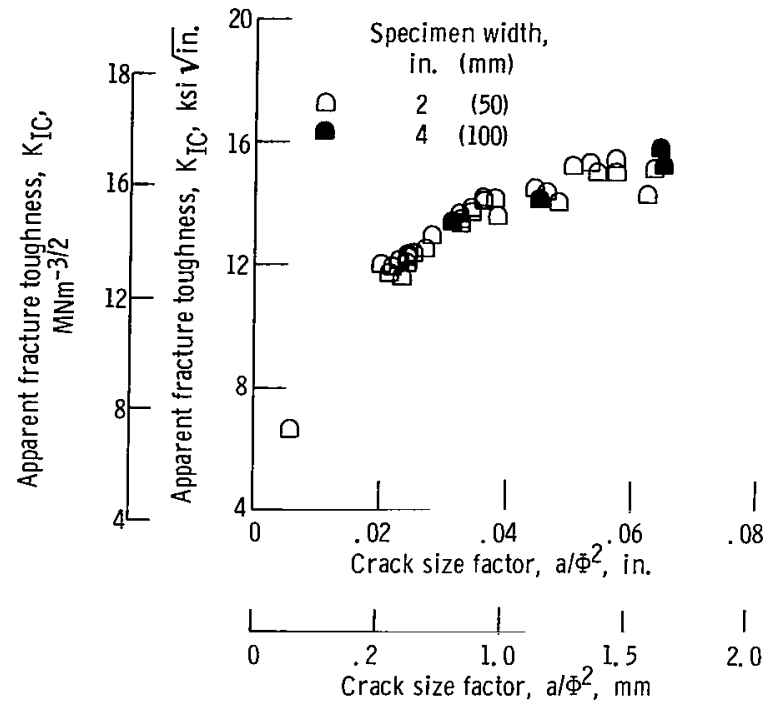

(a) Variation of apparent fracture toughness $\left(\mathrm{K}_{\mathrm{IC}}\right)$ with crack size.

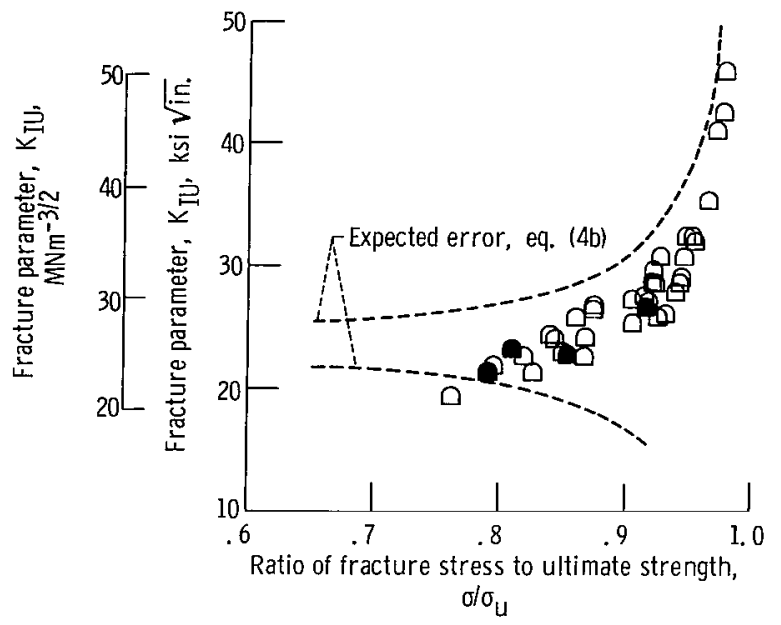

(c) Distribution of $\mathrm{K}_{\mathrm{IU}}$ values as function of fracture stress ratio.

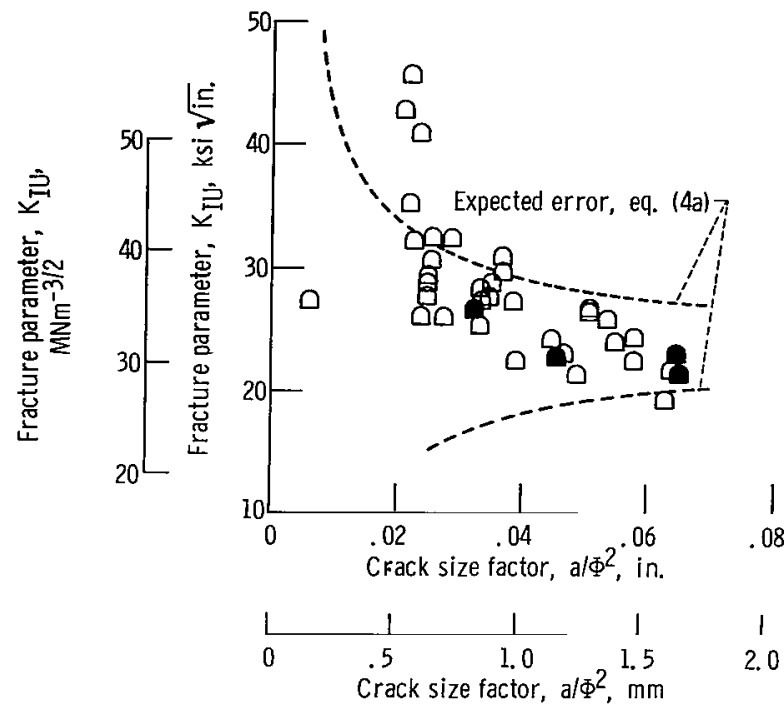

(b) Distribution of $\mathrm{K}_{\mathrm{IU}}$ values as function of crack size factor.

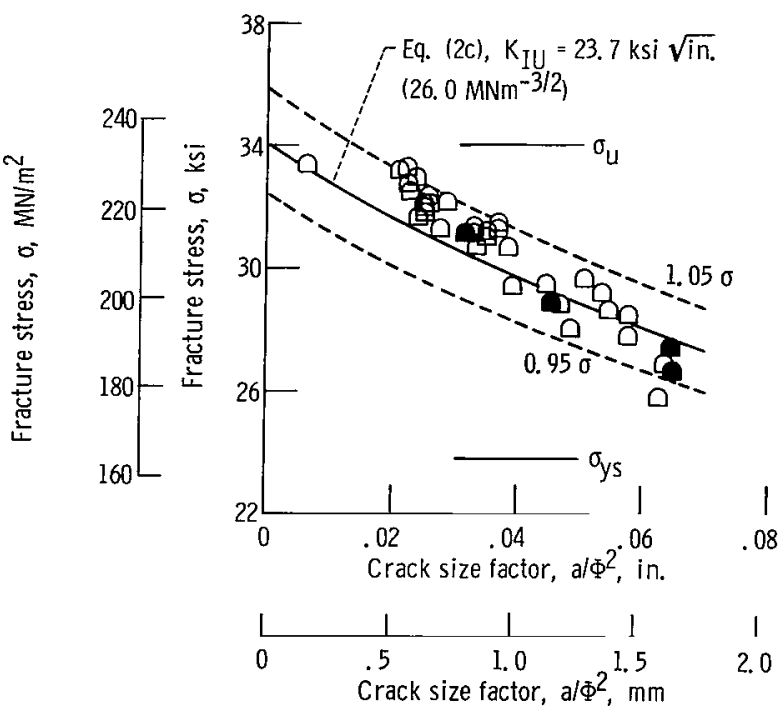

(d) Fracture stress as function of crack size factor.

Figure 3. - Fracture parameters for magnesium alloy HM21A-T8, 0.143 inch $(3.6 \mathrm{~mm})$ thick, longitudinal grain (data from ref. 9). 


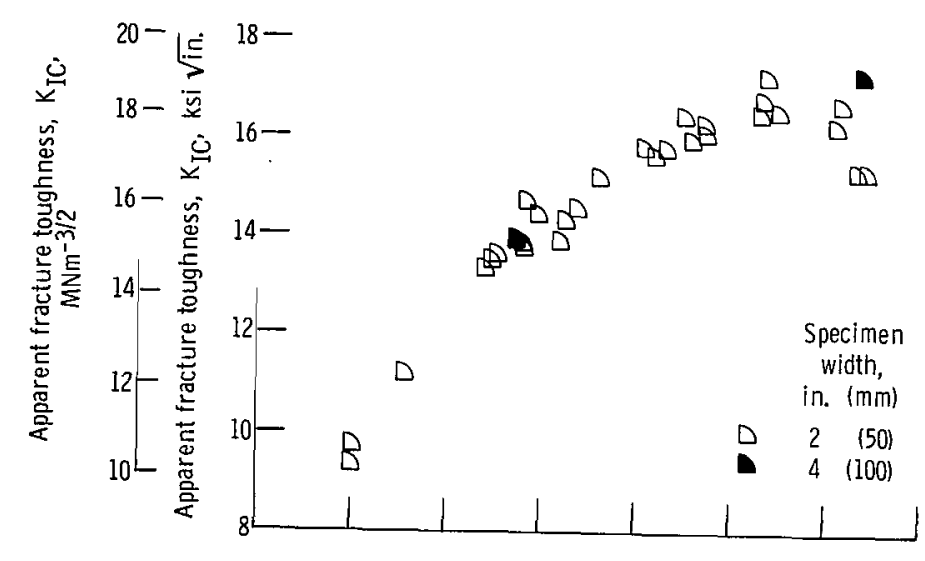

(a) Variation of apparent fracture toughness $\left(\mathrm{K}_{\mathrm{IC}}\right)$ with crack

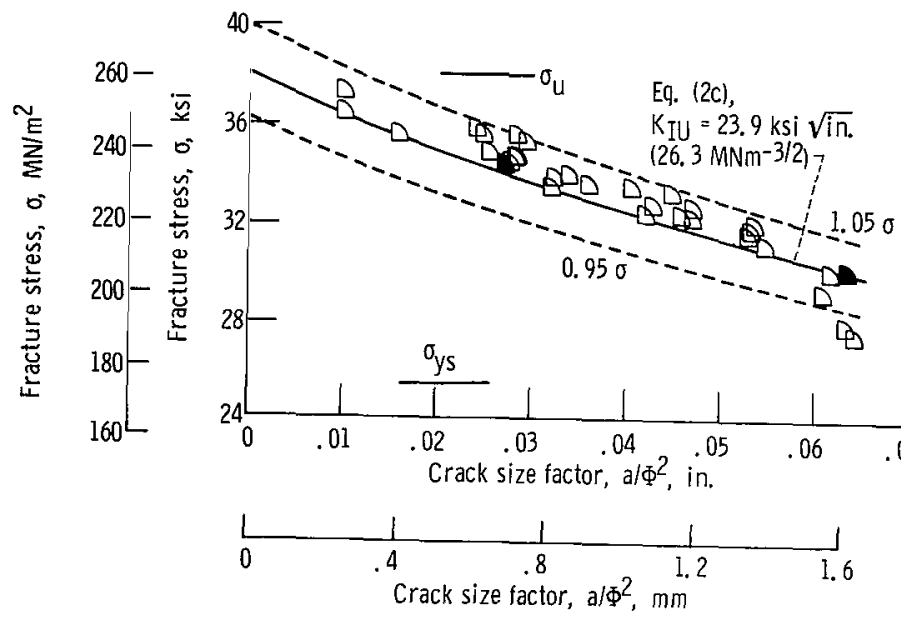

(b) Fracture stress as function of crack size factor.

Figure 4. - Fracture parameters for magnesium alloy HM21A- $18,0.143$ inch $(3.6 \mathrm{~mm})$ thick, transverse grain. (Data from ref. 9.)
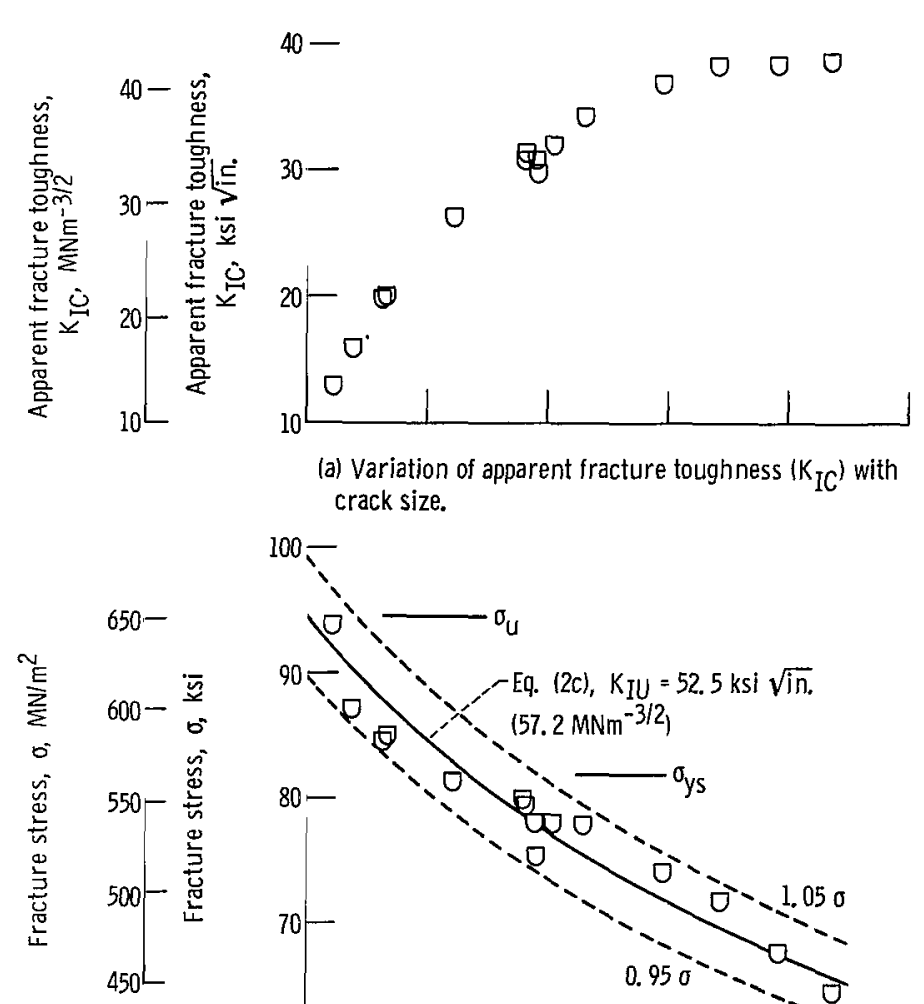

$100-$
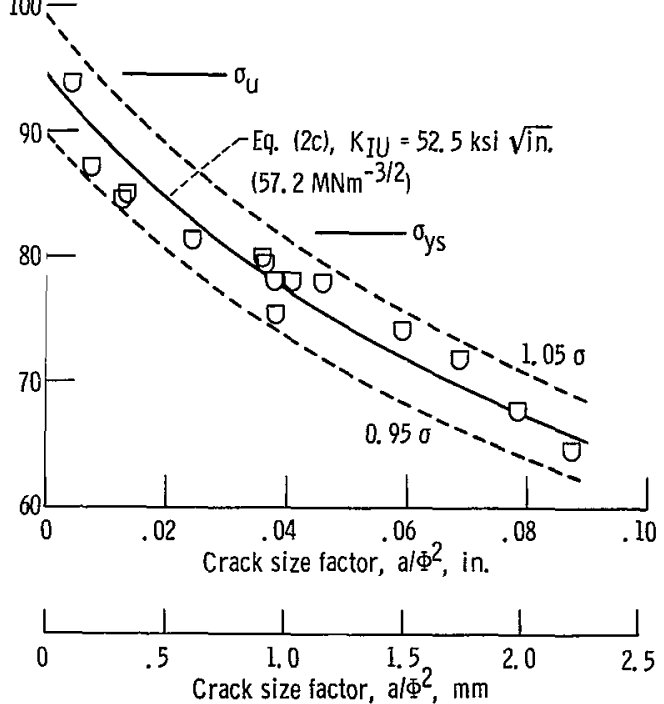

(b) Fracture stress as function of crack size factor.

Figure 5. - Fracture parameters for aluminum alloy 2014-T65l, 3/8 inch $(9.5 \mathrm{~mm})$ thick, tested at $-423^{\circ} \mathrm{F}(20 \mathrm{~K})$. (Data from ref. 10.) 

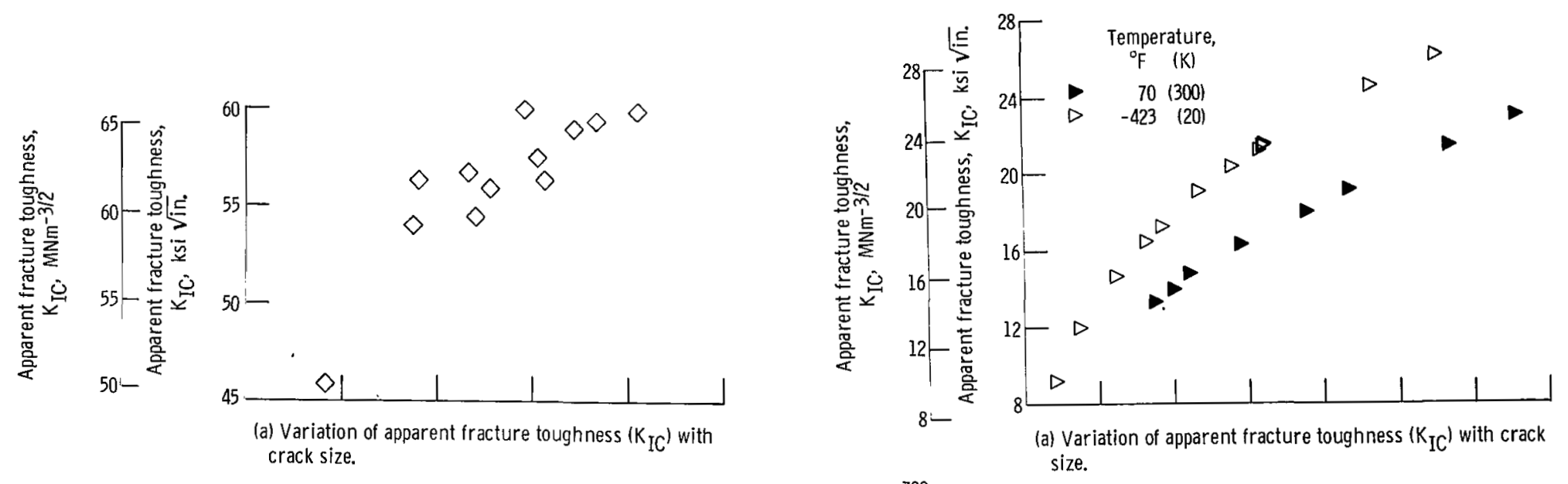

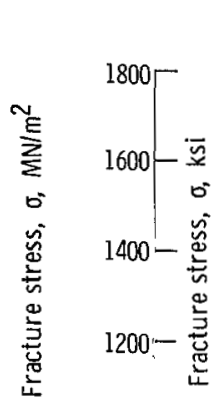

$1000-$

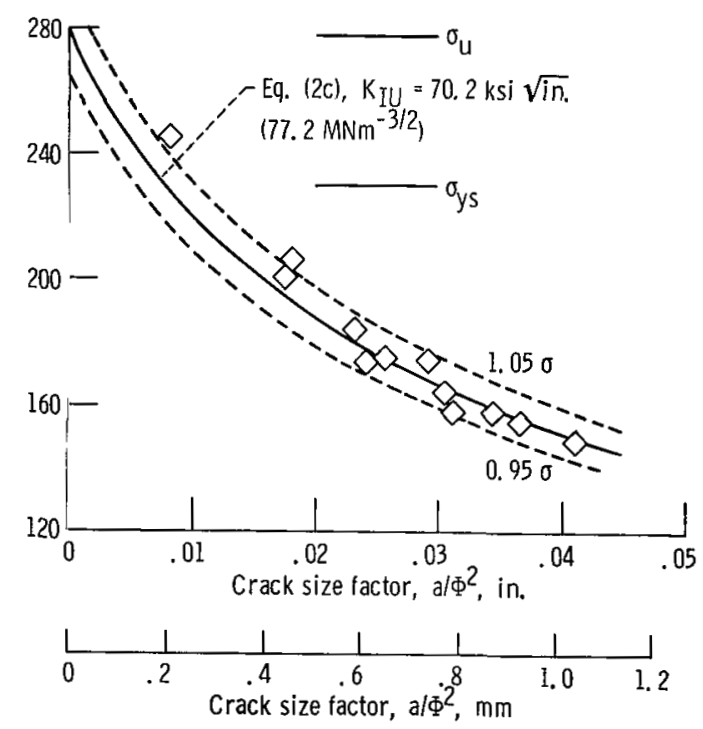

(b) Fracture stress as function of crack size factor.

Figure 6. - Fracture parameters for heat-treated AISI 4340 steel, $1 / 4 \mathrm{inch}(6.3 \mathrm{~mm})$ thick. (Data from ref. 10.)

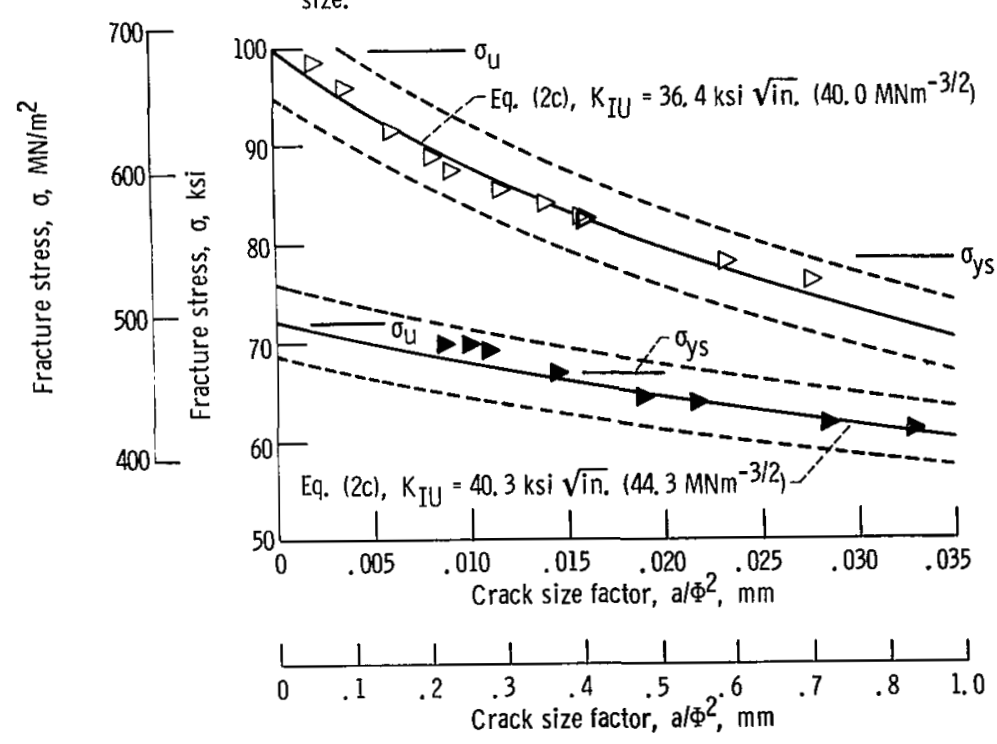

(b) Fracture stress as function of crack size factor. (Dashed curves indicate eq. (2c) \pm 5 percent.)

Figure 7. - Fracture parameters for 2014-T6 aluminum alloy, 0.1 inch $(2.5 \mathrm{~mm})$ thick (Data from ref. 11 .) 

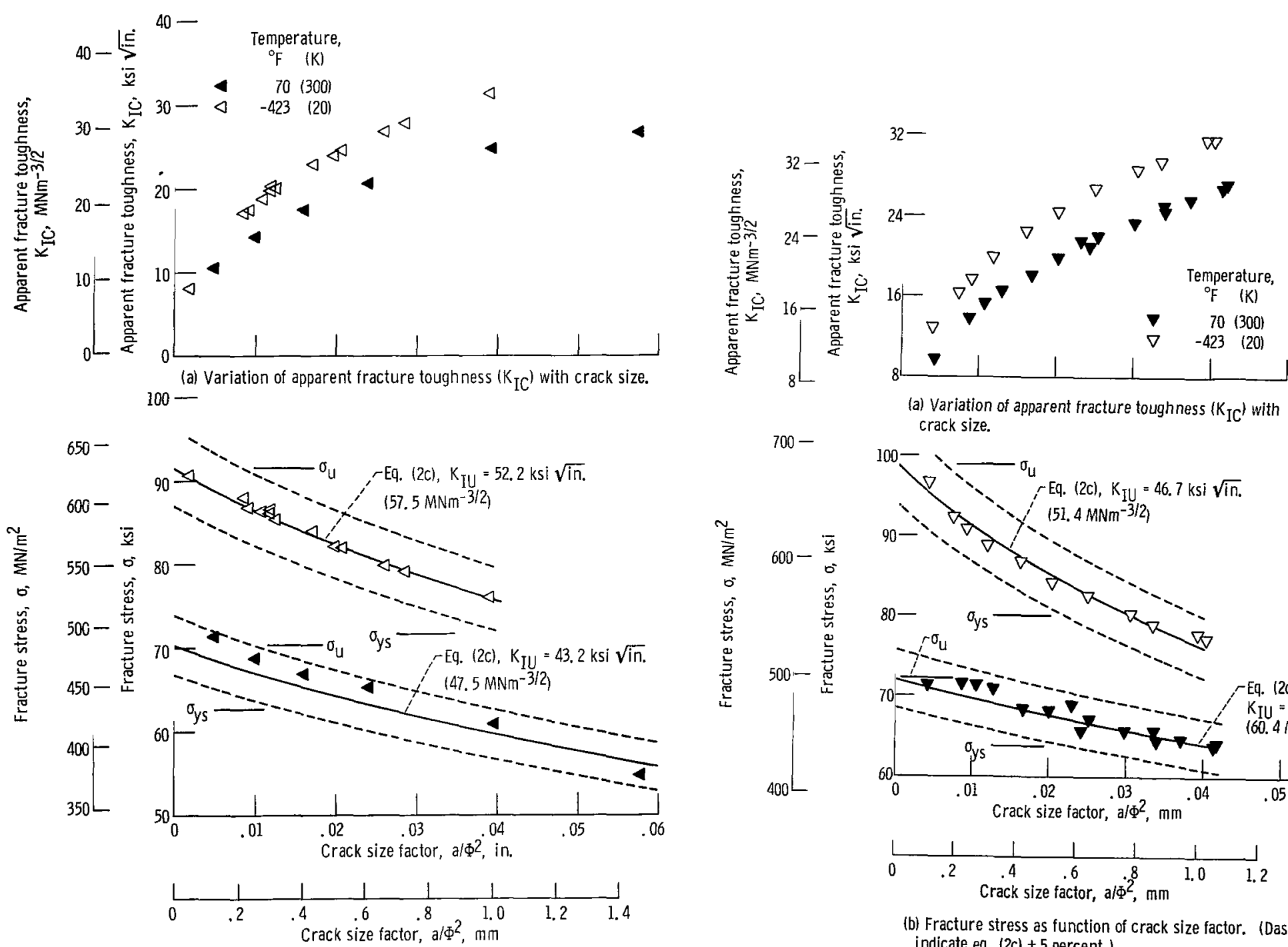

(a) Variation of apparent fracture toughness $\left(\mathrm{K}_{\mathrm{IC}} \mathrm{l}\right.$ with crack size.

(b) Fracture stress as function of crack size factor. (Dashed curves indicate eq. (2c) \pm 5 percent.)

Figure 8. - Fracture parameters for 2014-T6 al uminum alloy, 0.25 inch $(6.3 \mathrm{~mm})$ thick. (Data from ref. 11.$)$

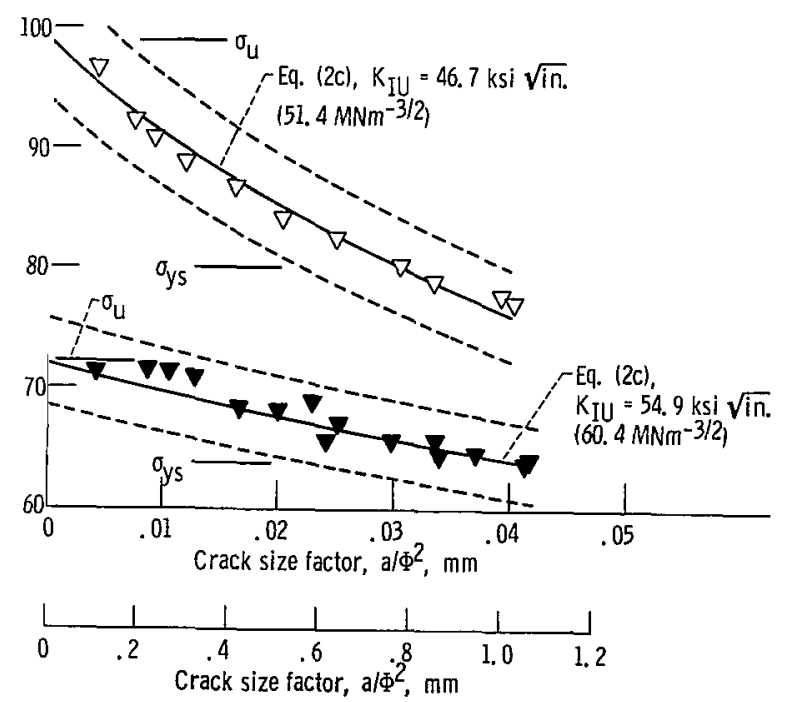

(b) Fracture stress as function of crack size factor. (Dashed curves indicate eq. (2c) \pm 5 percent.)

Figure 9. - Fracture parameters for 2014-T6 aluminum alloy parent metal, 0.25 inch $(6.3 \mathrm{~mm})$ thick. (Data from ref. 12.) 


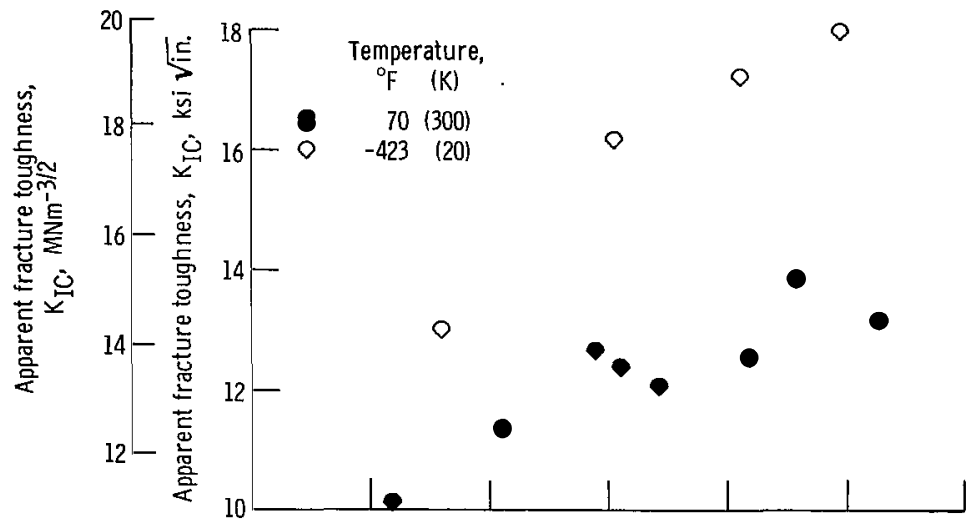

(a) Variation of apparent fracture toughness $\left(\mathrm{K}_{\mathrm{IC}}\right)$ with crack size.
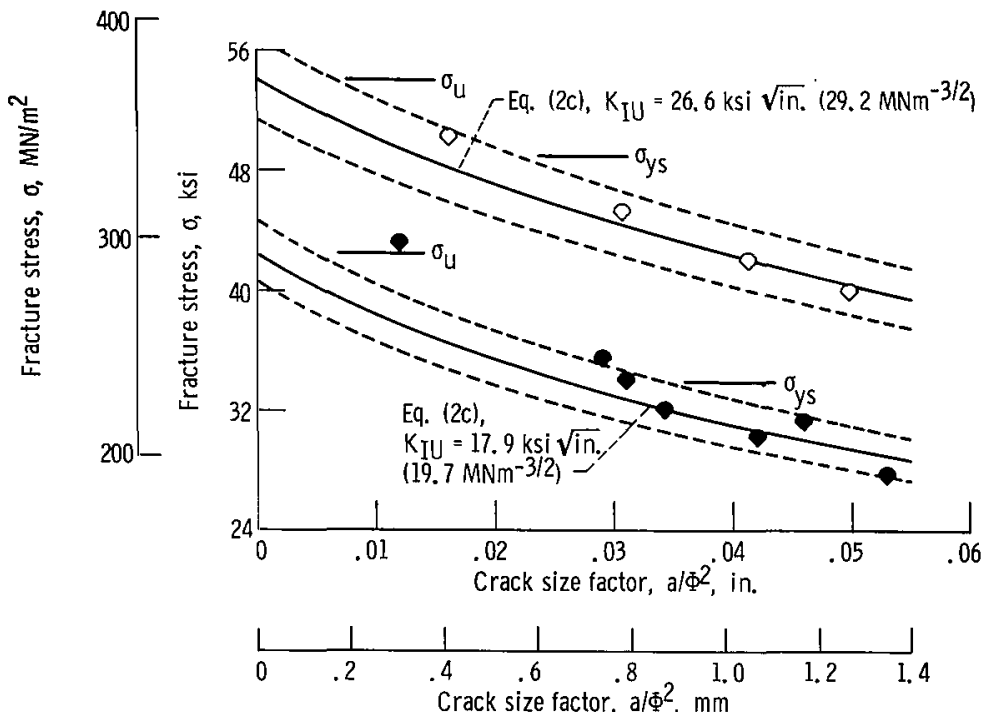

(b) Fracture stress as function of crack size factor. (Dashed curves indicate eq. (2c) \pm 5 percent)

Figure 10. - Fracture parameters for 2014-T6 aluminum alloy 0.25 inch $(6.3 \mathrm{~mm})$ thick, welded with 4043 filler wire. (Data from ref. 12.)
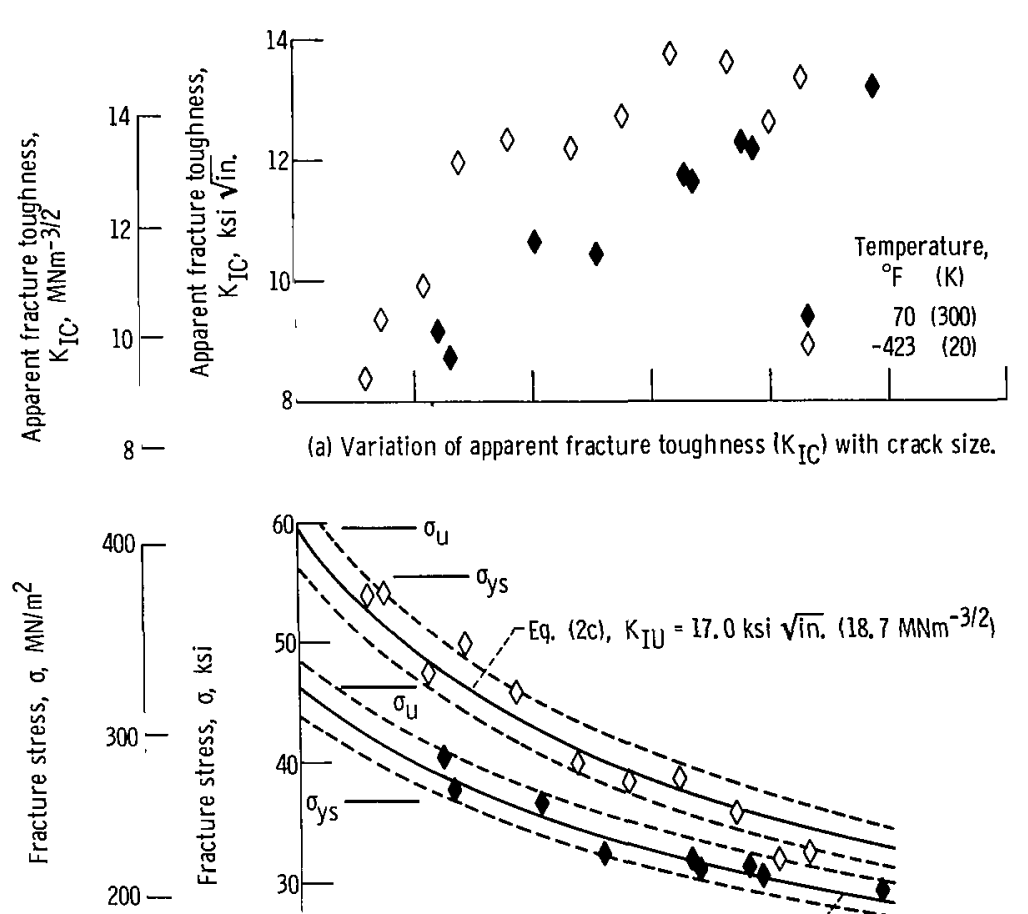

Eq. (2c), $\mathrm{K}_{\mathrm{IU}}=15.6 \mathrm{ksi} \sqrt{\mathrm{in} .}\left(17.1 \mathrm{mNm}^{-3 / 2}\right) \alpha^{\prime}$
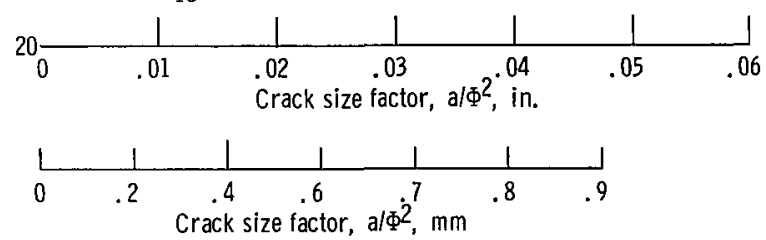

(b) Fracture stress as function of crack size factor. (Dashed curves indicate eq. (2c) \pm 5 percent)

Figure 11. - Fracture parameters for 2014-T6 aluminum alloy 0.25 inch $(6.3 \mathrm{~mm})$ thick, welded with 716 filler wire. (Data from ref. 12.) 


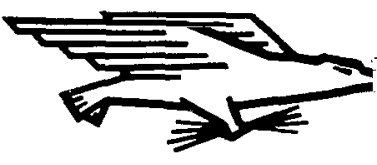

POSTAGE AND FEES PAID NATIONAL AERONAUTICS AN SPACE ADMINISTRATION

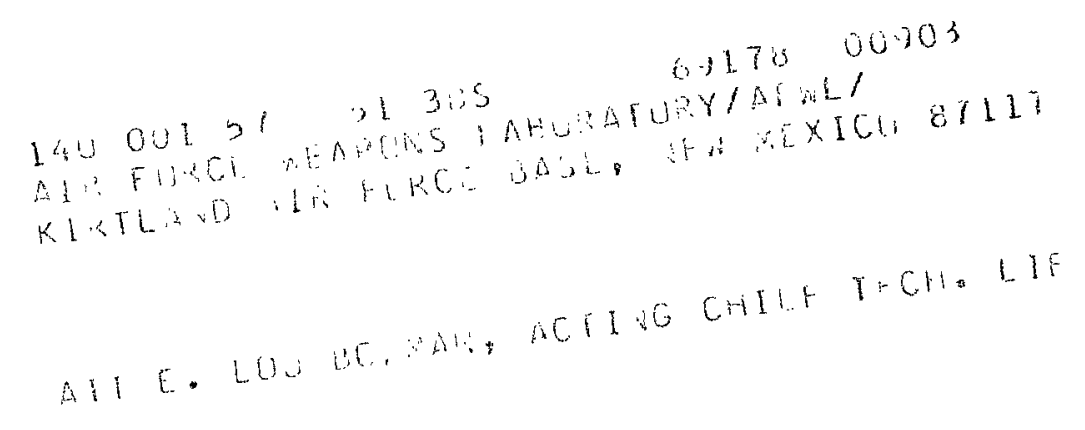

$\begin{array}{ll}\text { POSTMASTER: } & \text { If Undeliverable (Section } 158 \\ \text { Postal Manual) Do Not Return }\end{array}$

"The aeronatitical and space activities of the United States sball be conducted so as to contribute . . to the expansion of buman knowledge of phenomena in the atmosphere and space. The Administration shall provide for the widest practicable and appropriate dissemination of information concerning its activities and the results thereof."

- National. Aeronautics and Space Act of 1958

\section{NASA SCIENTIFIC AND TECHNICAL PUBLICATIONS}

TECHNICAL REPORTS: Scientific and technical information considered important, complete, and a lasting contribution to existing knowledge.

TECHNICAL NOTES: Information less broad in scope but nevertheless of importance as a contribution to existing knowledge.

TECHNICAL MEMORANDUMS: Information receiving limited distribution because of preliminary data, security classification, or other reasons.

CONTRACTOR REPORTS: Scientific and technical information generated under a NASA contract or grant and considered an important contribution to existing knowledge.

\author{
TECHNICAL TRANSLATIONS: Information \\ published in a foreign language considered \\ to merit NASA distribution in English.
}

SPECIAL PUBLICATIONS: Information derived from or of value to NASA activities. Publications include conference proceedings, monographs, data compilations, handbooks, sourcebooks, and special bibliographies.

\section{TECHNOLOGY UTILIZATION}

PUBLICATIONS: Information on technology used by NASA that may be of particular interest in commercial and other non-aerospace applications. Publications include Tech Briefs, Technology Utilization Reports and Notes, and Technology Surveys.

Details on the availability of these publications may be obtained from:

SCIENTIFIC AND TECHNICAL INFORMATION DIVISION

NATIONAL AERONAUTICS AND SPACE ADMINISTRATION

Washington, D.C. 20546 